\begin{tabular}{|c|c|}
\hline Title & $\begin{array}{l}\text { Mobilization and speciation of arsenic from hydrothermally altered rock in laboratory column experiments under } \\
\text { ambient conditions }\end{array}$ \\
\hline Author(s) & Tabelin, Carlito Baltazar; Igarashi, Toshifumi; Takahashi, Ryohei \\
\hline Citation & $\begin{array}{l}\text { A pplied Geochemistry, 27(1), 326-342 } \\
\text { https://doi.org/10.1016/.apgeochem.2011.10.007 }\end{array}$ \\
\hline Issue Date & $2012-01$ \\
\hline Doc URL & http:/hdl.handle.net/2115/48292 \\
\hline Type & article (author version) \\
\hline File Information & A G27-1_326-342.pdf \\
\hline
\end{tabular}

Instructions for use 


\title{
Mobilization and speciation of arsenic from hydrothermally altered rock in laboratory column experiments under ambient conditions
}

\author{
Carlito Baltazar Tabelin*a ${ }^{\mathrm{a}}$, Toshifumi Igarashi ${ }^{\mathrm{a}}$ and Ryohei Takahashi ${ }^{\mathrm{b}}$ \\ a Laboratory of Groundwater and Mass Transport, Division of Field Engineering for Environment, Graduate School of \\ Engineering, Hokkaido University, Sapporo 060-8628, JAPAN \\ ${ }^{\mathrm{b}}$ Department of Earth Science and Technology, Graduate School of Engineering and Resource Science, Akita University, \\ Akita 010-8502, JAPAN \\ E-mails: carlito@trans-er.eng.hokudai.ac.jp, tosifumi@eng.hokudai.ac.jp and ryohei@gipc.akita-u.ac.jp
}

\begin{abstract}
This paper describes the mobilization and speciation of arsenic (As) found in hydrothermally altered rock under oxic column conditions. The altered rock sample was obtained from a tunnel project located in the Nakakoshi area of Hokkaido, Japan, whose geology is represented by slate, shale and sandstone. This area underwent silicification, pyritization and argillic alteration resulting in the As-enrichment of the rock. Results of the column experiments show that the infiltration rate, bulk density and rock bed thickness affected the duration of water residence, which in turn influenced the $\mathrm{pH}$ of the rock-water system. Coexisting ions most notably calcium $\left(\mathrm{Ca}^{2+}\right)$ at amounts greater than ca. $50 \mathrm{mg} / \mathrm{L}$ retarded the mobilization of As. Mobilization of As from the rock with time occurred in two stages: stage 1 (weeks $1-$ 20) with higher As leaching and stage 2 (weeks 20 - 76) characterized by nearly constant As release. In addition, pore water As concentrations revealed that the columns developed into two regions: the top half where most of the leaching occurred and the bottom part dominated by adsorption. Thus, the mechanisms controlling the mobilization of As from the rock is a combination of one or more of the following processes: dissolution of soluble As-bearing fractions, pyrite oxidation and adsorption reactions. Arsenite (As[III]) was the dominant species in the effluent at the start of the experiment in columns with shorter water residence time and lower $\mathrm{pH}$ conditions $(<8)$. On the other hand, arsenate $(\mathrm{As}[\mathrm{V}])$ was the major inorganic species released from the rock at higher $\mathrm{pH}(8-9.5)$ and when the system was close to equilibrium. Speciation of As with depth also indicated that As[III] disappeared around the bottom half of the columns, probably as a result of adsorption and/or oxidation. Arsenic speciation is partially controlled by the $\mathrm{pH}$ dependent adsorption of As species. The important adsorbent phases in the rock included Fe-Al oxides/oxyhydroxides, clay minerals and organic matter, which permitted the columns to attenuate additional As loadings including As[III]. Implications of these results on the design of a novel disposal method for these altered rocks include the enhancement of As adsorption through the addition of natural or artificial adsorbents and the utilization of a covering soil with low permeability to minimize rainwater infiltration into the rock.
\end{abstract}

Keywords: Leaching; speciation; arsenic; redox reactions; column experiments

*Corresponding author: Tel: +81-11-706-6311 Fax: +81-11-706-6308

email: carlito@trans-er.eng.hokudai.ac.jp 


\section{INTRODUCTION}

Arsenicosis, keratosis and cancers of the skin, kidney and lungs are some of the serious health problems associated with prolonged exposure to arsenic (As)-contaminated soil and groundwater (O’Day et al., 2004; Sengupta, 2002). The most well known and notorious example of As contamination of groundwater are those reported in Bangladesh and West Bengal, India, which is affecting as many as 70 million people (Acharyya et al. 2000; Akai et al., 2004; Das et al., 1996; Dowling et al., 2002; Nickson et al., 2000). Aside from the well documented toxicity of As, it is especially problematic because of its high mobility under varying $\mathrm{pH}$ and redox conditions. Even at reducing conditions when other oxyanions like those of chromium $(\mathrm{Cr})$ and selenium $(\mathrm{Se})$ are already precipitated, As is still mobile because of the reductive dissolution of Feoxyhydroxides/oxides that have high As adsorption affinity and the reduction of As[V] to As[III] (Smedley and Kinniburgh, 2002).

Recent tunnel projects in Japan for roads and other purposes have excavated rocks that had been hydrothermally altered. Because of this, the rocks contain elevated amounts of As and other toxic elements (e.g., lead $(\mathrm{Pb}), \mathrm{Cr}$, Se and boron $(\mathrm{B}))$, and are therefore potential sources of contamination. At the moment, special landfills are being used for the disposal of these hazardous waste rocks, but this is so expensive that new and alternative methods are being explored.

One of these projects is a tunnel constructed in the Nakakoshi area of Kamikawa province (Hokkaido, Japan), which is 3.3 kilometers long and is a part of the national highway built to connect the cities of Asahikawa and Monbetsu. The geology of this area is represented by Cretaceous slate and alternation of shale and sandstone of the Nakakoshi Formation, as basement rock of the province, belonging to the Hidaka Supergroup. The Nakakoshi Formation in the area 
is intruded by biotite granite, quartz diorite, diabase, porphyrite and rhyolite. The intrusion of quartz diorite caused a low-grade contact metamorphism, forming silicification and pyrite dissemination of the host rock. The intrusion age of quartz diorite is 11.2 Ma based on fission track method (Koshimizu and Kim, 1986). The rocks mentioned above are covered by Neogene rhyolite lava and pyroclastic basaltic andesite.

Hydrothermally altered rock extends from the mouth to more than 175 meters into this tunnel. A mineralized zone accompanies the hydrothermal alteration with a maximum width of 2.5 meters composed of quartz-pyrite vein and veinlets. A strongly altered andesitic dike of 4 meters in width was observed near the center of the alteration zone. It is known that there is an As- and $\mathrm{Cu}$ - bearing polymetallic deposit (Nakakoshi deposit), located $7 \mathrm{~km}$ southeast from the project area (Tsushima et al., 1999). Both are quartz veins and show the same E-W orientation, so they may be associated in genesis. In the project area, the hydrothermal alteration of slate is characterized by silicification, pyritization and argillic alteration of kaolinite resulting in high As abundances in the rock (up to $513 \mathrm{mg} / \mathrm{kg}$ ). A detailed study of the geology, mineralogy and alteration of the tunnel project area can be found elsewhere (Takahashi et al., 2011).

Numerous studies have been reported about the hydrothermal alteration of rocks especially in the context of ore genesis, characterization and formation (Aiuppa et al., 2006; Allen and Hahn, 1994; Halbach et al., 1993; Horton et al., 2001; Huston et al., 1995; Ostwald and England, 1977). Also, several authors have studied the evolution of toxic elements including As and heavy metals from mine pit lakes that are in contact with hydrothermally altered rock (Davis and Ashenberg, 1989; Davis et al., 2006; Eary, 1998; Levy et al., 1997; Savage et al., 2009; Tempel et al., 2000), but studies regarding the leaching behavior and release mechanisms of As from excavated altered rocks and the parameters that control these mechanisms are still lacking in the 
literature. Understanding of these release and speciation mechanisms is essential in the development of any engineered countermeasures that would minimize As mobilization from altered rocks. Our previous research pointed out the importance of $\mathrm{pH}$ and $\mathrm{Eh}$ in the mobilization of As from these rocks (Igarashi et al., 2008; Tabelin and Igarashi, 2009), but experimental conditions in these studies dramatically differ from those that would be encountered during the actual disposal of the rocks. Moreover, As speciation was not elucidated in detail in these previous papers. Thus, we used column experiments in this study to elucidate the short and long term effects of infiltration rate, bulk density (i.e., compaction) and rock bed thickness on the mobilization and speciation of As as well as the changes in the $\mathrm{pH}$ and Eh of the effluent from bulk excavated altered rocks.

The infiltration rate or the amount of rainfall is important because it controls the water residence time (i.e., length of time that the water is in contact with the rock), which in turn affects the extent of geochemical processes that mobilize or immobilize As. Bulk density is an essential parameter especially during the actual disposal of the altered rocks because of the movement of heavy machineries (e.g., dump trucks, backhoes and bulldozers) and compaction may be necessary for added structural stability. Also, the amount of As released from the altered rocks would depend on the quantity of waste rock disposed because from a "material balance" perspective; a larger mass of altered rocks means more sources of As.

We also elucidated the speciation of As from the rock under conditions close to equilibrium using batch experiments, which would be helpful in the interpretation of the results from the column experiments. Furthermore, we employed sequential extraction on the samples before and after the column experiments to understand the changes that occurred on the As-bearing solid fractions of the rock. Finally, geochemical modeling was applied to aid our understanding of the 
mechanism/s controlling the mobilization and speciation of As from the altered rock. Data from this study would not only expand our knowledge regarding the mobilization and speciation of As from these particular sources but also help in the design of an alternative disposal method for these hazardous waste rocks.

\section{MATERIALS AND METHODS}

\subsection{Sample collection}

During the tunnel construction, excavated rocks from the first $175 \mathrm{~m}$, whether altered or unaltered, were collected, transported and stored together. The hydrothermally altered rock used in this study was collected from the interim storage site built to accommodate the As-rich excavated rocks. This interim storage site is lined with asphalt and has a built-in drainage system to collect the contaminated water from the rock. Prior to our sample collection, the excavated rock had been exposed to the environment for about 6 months. Sampling was done using a shovel at random points of the impoundment. Sizes of rock collected ranged from large (ca. 20 $\mathrm{cm}$ in diameter) to fine $(<2 \mathrm{~mm}$ in diameter). We collected the sample used in our experiments from the bulk excavated rock, which was largely composed of altered rocks. Although it had minor amounts of unaltered rocks, we believe that it would still closely represent the mobilization of As from excavated hydrothermally altered rocks because the unaltered state usually has lower As content (Tanaka, 1988). Moreover, using the rock mixture will have more relevance to the design of the disposal method because it represents the properties of actual excavated rocks for disposal. 


\subsection{Sample preparation and characterization}

The sample from the bulk excavated rock was air dried, crushed using a jaw crusher and sieved through a $2 \mathrm{~mm}$ aperture screen. We chose the particle size of less than $2 \mathrm{~mm}$ for the experiments because it represented the most reactive portion of the actual waste rock. The screened portion was then mixed thoroughly and stored in an air tight container to minimize exposure to moisture. Particle size distribution of the sample was determined using sieve analysis. For the chemical and mineralogical analysis, the sample was further ground to $<50 \mu \mathrm{m}$. The chemical composition of the rock was analyzed using an X-ray fluorescence spectrometer (XRF), XEPOS (Rigaku Corporation, Japan), while the constituent minerals of the sample were identified using an X-ray diffractometer (XRD), MultiFlex (Rigaku Corporation, Japan). Loss on ignition was determined through gravimetry by heating the sample $(<2 \mathrm{~mm})$ inside a furnace at $750^{\circ} \mathrm{C}$ for 1 hour after drying in an oven at $110^{\circ} \mathrm{C}$ for 24 hours. Organic matter in the rock was indirectly measured from the total carbon content (TC) and inorganic carbon content (IC). The TC and IC were measured using a total carbon analyzer attached to a solid sample combustion unit (TOC- $\mathrm{V}_{\mathrm{CSH}^{-}}$ SSM-5000A, Shimadzu Corporation, Japan).

The sequential extraction procedure used in this study was devised by Marumo et al. (2003) for the determination of the leachabilities of toxic elements including As from soils and sediments. Marumo et al. (2003) developed their method based on the procedures of Tessier et al. (1979) and Clevenger (1990). Details of the sequential extraction procedure used in this study are summarized in Table 1 . For the procedure, $1.0 \mathrm{~g}$ of the $<2 \mathrm{~mm}$ crushed hydrothermally altered rock sample was used. The residue was washed with $10-15 \mathrm{ml}$ of deionized water after each extraction step. The leachate and water used for washing were then combined and diluted to $50 \mathrm{ml}$ for analysis. The exchangeable fraction included both strongly and weakly adsorbed As 
while the Fe-Mn oxide fraction corresponded to As incorporated into these oxides that are unstable under reducing conditions. The residual fraction was determined from the difference between the total amount of As and the total As extracted from the sample.

\subsection{Batch leaching experiments}

Batch leaching experiments were done under ambient conditions using solid-liquid ratios of 1:5 and 1:10 at mixing times of $0.5,2,6,10$ and 24 hours. In all the batch experiments, deionized

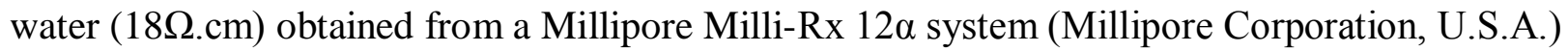
was used as leachant. The $\mathrm{pH}$ and Eh were measured after the predetermined mixing time, the leachate filtered through Millipore ${ }^{\circledR}$ sterile filters (Millipore Corporation, USA) and then stored at $6^{0} \mathrm{C}$ prior to the chemical analysis.

\subsection{Column experiments}

\subsubsection{Apparatus}

Six columns were constructed and placed under ambient conditions exposed to atmospheric $\mathrm{O}_{2}$ and $\mathrm{CO}_{2}$. The columns are made of PVC tubes mounted on top of a steel stand with each stand accommodating 3 columns. The columns have heights of $350 \mathrm{~mm}$ and inner diameters of $52 \mathrm{~mm}$. Covers were also designed with small holes to simulate rain and protect the column from outside contaminants and dust. A schematic diagram and details of the column dimensions are shown in Figure 1.

\subsubsection{Initial parameters}

The degree of compaction in five of the columns was standardized by compacting 344 grams of the sample to a thickness of $10 \mathrm{~cm}$ for a bulk density of $1.62 \mathrm{~g} / \mathrm{cm}^{3}$ and porosity equal to $40.7 \%$. 
This procedure was repeated until the desired rock bed thickness was achieved. The column without compaction was constructed by using $688 \mathrm{~g}$ of the sample that was equivalent to the weight used in the column with compaction. The sample in the column without compaction had a lower bulk density $\left(1.47 \mathrm{~g} / \mathrm{cm}^{3}\right)$ and a higher porosity $(46.2 \%)$ compared to those with compaction.

\subsubsection{Influent parameters}

Details of the column experimental conditions and setup are summarized in Table 2. Water addition of $40 \mathrm{~mm} /$ week is equivalent to the average annual rainfall in high precipitation areas of Japan. For the remainder of this paper, the columns are referred to by the following notations:

- Columns with varying infiltration rates are called IR-cases 1,2 and 3 corresponding to 20, 40 and $80 \mathrm{~mm} /$ week of rainfall, respectively.

- Columns with different bulk densities are called BD-cases 1 (compacted) and 2 (uncompacted).

- Columns with different rock bed thicknesses are referred to as RT-cases 1, 2 and 3 for rock bed thicknesses of 100, 200 and $250 \mathrm{~mm}$, respectively.

Note that IR-case 2, BD-case 1 and RT-case 2 corresponded to the same column. Individual names were assigned to each parameter for easy comparison and to minimize confusion.

Tracer and As concentration spike tests were conducted in RT-cases 1, 2 and 3 after week 76. Potassium bromide $(\mathrm{KBr})$ was used as a tracer and both $\mathrm{As}[\mathrm{III}]$ and $\mathrm{As}[\mathrm{V}]$ were utilized in the spike tests. For the tracer and spike tests, $100 \mathrm{mg} / \mathrm{L}$ of $\mathrm{KBr}$ was added in the three cases together with $10,000 \mu \mathrm{g} / \mathrm{L}$ of As. Arsenic[V] was the As species added into RT-cases 1 and 2 while As[III] was introduced into RT-case 3. Ten weeks later, the tracer tests were completed. We increased the infiltration rates of RT-cases 2 and 3 from 40 to $140 \mathrm{~mm} /$ week to check the 
stability of As immobilized in the columns. This could also simulate worst case scenarios like flooding or abnormally high rainfall during the actual disposal of the rock.

\subsubsection{Effluent collection}

Deionized water $(18 \Omega . \mathrm{cm})$ was introduced into the top of the column once a week and allowed to flow down by gravity. After about 2 days, the effluents were collected, and the $\mathrm{pH}$, Eh and

electrical conductivity (EC) were measured. After that, the effluents were filtered through a 0.45 $\mu \mathrm{m}$ Millipore ${ }^{\circledR}$ sterile filter and then stored at $6^{\circ} \mathrm{C}$ prior to the chemical analyses.

The pore volume (PV) in each column was calculated from (American Society for Testing Materials, 1989):

$$
P V=V-\frac{M}{[(1+w) * S * D]}
$$

where, $P V$ : pore volume $\left(\mathrm{cm}^{3}\right)$,

$V$ : as-packed volume $\left(\mathrm{cm}^{3}\right)$,

$M$ : as-packed weight, including moisture (g),

$w$ : moisture content (unit less),

$S:$ specific gravity, and

$D$ : density of water $\left(\mathrm{g} / \mathrm{cm}^{3}\right)$

The hydrothermally altered rock in the columns underwent compaction after the first PV of effluent collection. The thickness of the rock beds decreased by ca. $5 \mathrm{~mm}$ in IR-cases 1,2 and 3, ca. $8 \mathrm{~mm}$ in BD-case 2 , ca. $2 \mathrm{~mm}$ in RT-case 1 and ca. $5 \mathrm{~mm}$ in RT-case 3 . After that, the thickness of the rock beds remained virtually constant. The change in the thickness of the rock beds after the first PV was incorporated in our calculations (Table 2). 


\subsubsection{Post-experimental characterization}

After 32 weeks, all the cases appeared to have reached steady state. IR-cases 1, 3 and BD-case 2 were stopped while RT-cases 1, 2 and 3 were continued to evaluate the long term evolution of $\mathrm{pH}$, Eh, As and coexisting ions. IR-case 3 was divided into $25 \mathrm{~mm}$-sections, air dried, lightly crushed using mortar and pestle, and mixed thoroughly. Sequential extraction was done on each of the sections using the procedure discussed earlier. IR-case 3 was selected as the representative column because it was not spiked with any As species. In addition, it released the highest amount of As among the un-spiked columns, which could be beneficial in the comparison of the initial and the "leached" samples.

The remaining column experiments were stopped after 90 weeks and sectioned. Each section was ca. $25 \mathrm{~mm}$ thick and pore waters from these sections were collected using a centrifuge. The water content was then gravimetrically determined by drying the centrifuged sections.

\subsection{Chemical Analysis}

Dissolved As concentration greater than $0.1 \mathrm{mg} / \mathrm{L}$ was analyzed using an inductively coupled plasma atomic emission spectrometer (ICP-AES) (ICPE - 9000, Shimadzu Corporation, Japan). Low As concentrations $(<0.1 \mathrm{mg} / \mathrm{L})$ were analyzed using a hydride generation attachment coupled with the ICP-AES. In preparation for the hydride generation analysis, $30 \mathrm{ml}$ of leachate was mixed with $15 \mathrm{ml}$ of $12 \mathrm{M} \mathrm{HCl}, 2 \mathrm{ml}$ of $20 \%$ potassium iodide (KI) solution, $1 \mathrm{ml}$ of $10 \%$ ascorbic acid solution and diluted with deionized water to $50 \mathrm{ml}$. All chemicals used in the preparation and analysis were reagent grade. Sulfur in the leachate was predominantly in the form of sulfate $\left(\mathrm{SO}_{4}{ }^{2-}\right)$ based on the results of anion chromatography (ICS - 90, Dionex Corporation, USA), so for faster and easier determination of $\mathrm{SO}_{4}{ }^{2-}$, the ICP-AES was used. Coexisting ions like $\mathrm{Ca}, \mathrm{Si}, \mathrm{Al}$ and $\mathrm{Fe}$ with concentrations greater than $0.1 \mathrm{mg} / \mathrm{L}$ were also 
analyzed using the standard ICP-AES method, but lower concentrations $(<0.1 \mathrm{mg} / \mathrm{L})$ were analyzed using an ultrasonic aerosol generator attached to the ICP-AES. The standard ICP-AES method has a margin of error of ca. $2-3 \%$ while more sensitive hydride generation and ultrasonic aerosol generator methods have uncertainties of ca. $5 \%$.

For the speciation of As, filtered and unacidified leachates were passed through WATERS Sep-Pak ${ }^{\circledR}$ Plus Acell Plus QMA cartridges (Waters, MA). These QMA cartridges are solid phase extraction cartridges able to immobilize As[V] while allowing As[III] to pass through (Impellitteri, 2004; Al-abed et al., 2006). The sample leachate passing through the QMA cartridges were collected and analyzed in terms of As[III]. Arsenate was then calculated from the total As and As[III] concentrations in the leachate.

\subsection{Geochemical modeling}

Saturation indices of important precipitates/minerals like sulfates, carbonates, oxides, oxyhydroxides and calcium arsenates that could potentially affect As leaching and mobility were calculated using an equilibrium geochemical modeling software called PHREEQC (Parkhurst and Appelo, 1999) using the THERMODEM database compiled by the French Geological Survey (BGRM Institute). Thermodynamic data and chemical reactions of four calcium arsenates $\left(\mathrm{Ca}_{5}\left(\mathrm{AsO}_{4}\right) \mathrm{OH}, \mathrm{Ca}_{3}\left(\mathrm{AsO}_{4}\right)_{2} \cdot 3 \mathrm{H}_{2} \mathrm{O}, \mathrm{Ca}_{4}(\mathrm{OH})_{2}\left(\mathrm{AsO}_{4}\right)_{2} \cdot 2 \mathrm{H}_{2} \mathrm{O}\right.$ and $\left.\mathrm{CaHAsO}_{4} \cdot 4 \mathrm{H}_{2} \mathrm{O}\right)$ used in the calculations were obtained from Bothe and Brown (1999) and Zhu et al. (2006). PHREEQC was also used to simulate an ideal system of pyrite and calcite. In this simulation, the amount of calcite and pyrite were 10 and 0.1 moles, respectively, and in equilibrium with pure water $(\mathrm{pH}$ 7). These values were selected because calcite was more abundant than pyrite in the sample and the deionized water used in the column experiments was ultra pure water $(18 \Omega . \mathrm{cm})$. In order to achieve the slightly alkaline $\mathrm{pH}$ observed in the experiments, we adjusted the concentrations of 
$\mathrm{O}_{2}$ and $\mathrm{CO}_{2}$ in the simulated system. Also, an $\mathrm{Eh}-\mathrm{pH}$ diagram showing the speciation of As was constructed using the Geochemist's Workbench ${ }^{\circledR}$ (Bethke, 1992) based on the actual effluent chemistry.

\section{RESULTS}

\subsection{Properties of the bulk rock used in the experiments}

The chemical and mineralogical compositions of the sample are summarized in Tables 3 and 4 , respectively. The As concentration of the sample was $23.6 \mathrm{mg} / \mathrm{kg}$, with low $\mathrm{S}$ and organic matter contents at 0.20 and $0.23 \%$ by weight, respectively. Hydrothermal alteration resulted in a large spatial variability of chemical and mineralogical composition as illustrated in Table 4. The unaltered rock was composed predominantly of quartz with traces of chlorite. On the other hand, the altered rock had a variety of minerals from silicates (e.g., quartz and plagioclase), carbonates (e.g., calcite) and sulfides (e.g., pyrite, arsenopyrite and marcasite) to alteration products (e.g., illite). The sample taken from the bulk excavated rock was a mixture of altered and unaltered rock and is primarily composed of silicate minerals (i.e., quartz and feldspar) with calcite as a minor mineral and trace amounts of pyrite (Table 4). The other minor minerals found in the rock include chlorite and kaolinite.

Most of the As content of the rock was associated with the oxidizable fraction (i.e., sulfides and organic matter) amounting to $55.2 \%$ of the total As content based on the sequential extraction results. Significant amounts of As were also found as exchangeable fraction (17.9\%), with carbonates $(2.3 \%)$ and with the reducible fraction (i.e., Fe-Mn oxides) (2.4\%). The remaining As was associated with the crystalline/residual phases (22.2\%) that are resistant to leaching under normal geochemical conditions. The sequential extraction was conducted only on 
one sample, which may not represent the exact amount of As in the actual bulk excavated rock. None the less, these values will give us good approximations of the relative abundance of As in these important As-bearing fractions. The particle size distribution of the rock after crushing is shown in Table 5. Based on the result, the sample used is classified as clayey sand and is a mixture of $70.4 \%$ sand, $22.3 \%$ silt and $7.3 \%$ clay. This particle size distribution was used in both the sequential and column experiments.

\subsection{Mobilization and speciation of As in batch leaching experiments}

The leaching behavior and speciation of As from the rock with time at different solid-liquid ratios are illustrated in Figure 2. For a solid-liquid ratio of 1:5, the total concentration of As in the leachate was already significant even just after 30 minutes $(18.5 \mu \mathrm{g} / \mathrm{L})$ and stabilized after 6 hours (Figure 2(a)). The amount of As[III] in the leachate after 30 minutes was negligible and most of the As released from the rock was in the +5 oxidation state. However after 30 minutes, the amount of As[III] increased and stabilized after 6 hours at a concentration range of $1.8-3.2$ $\mu \mathrm{g} / \mathrm{L}$, which is ca. $8-14 \%$ of the total As released from the rock. In contrast, the total concentration of As decreased in the leachate at a lower solid-liquid ratio of 1:10 (Figure 2(b)). The amount of As[III] released in the 1:10 ratio was in the range of $0.2-0.8 \mu \mathrm{g} / \mathrm{L}$ equivalent to $1-5 \%$ of the total As released from the rock, which was lower than those observed in the higher solid-liquid ratio of 1:5. In both cases, the major As species in the leachate regardless of the mixing time was As[V] amounting to as much as $99 \%$ of the total As released from the rock. The $\mathrm{pH}$ of the 1:10 ratio was also slightly higher than that of the 1:5 ratio, but both had a decreasing trend. On the other hand, the Eh curves have an increasing trend in both solid-liquid ratios, and are all greater than $+0.25 \mathrm{~V}$ indicating oxidizing conditions regardless of the mixing time (Figure 2(d)). 


\subsection{Column experiments: temporal changes}

\subsubsection{Infiltration rate}

The average volumetric water contents were $0.33,0.31$ and $0.32 \mathrm{~cm}^{3} / \mathrm{cm}^{3}$ for IR-cases 1,2 and 3 , respectively, which means that the size distribution (clayey sand) and bulk density $\left(1.62 \mathrm{~g} / \mathrm{cm}^{3}\right)$ used in these three cases could retain pore water at ca. $31-33 \%$ of the total volume independent of the infiltration rate (there was a vertical variability in water content). However, although the infiltration rate did not affect the amount of water retained in the columns, it controlled the water residence time in each column. In IR-case 1 (with the lowest infiltration rate), the first effluent sample was collected after 4 weeks, IR-case 2 after 2 weeks and IR-case 3 (with the highest infiltration rate) after only 1 week. To look at it in another perspective, it took more than 3 times (ca. 22 weeks) longer to collect 5 PV of effluent from IR-case 1 as compared to IR-case 3 (ca. 6 weeks) (Figure 3(a)).

The amount of water added into the column also affected the $\mathrm{pH}$ of the effluent as illustrated in Figure 3(b). The initial pH values in IR-cases 2 and 3 were close to each other while that of IR-case 1 was ca. $0.8 \mathrm{pH}$ unit lower. In IR-cases 2 and 3, the $\mathrm{pH}$ increased with time until a peak was reached followed by a gradual decrease prior to stabilization. Among these cases, the peak in IR-case 3 was highest (pH 9.44). However, this trend was not observed in IR-case 1(lowest infiltration rate). The range of $\mathrm{pH}$ values was also highest in IR-case $3(7.7-9.5)$ and lowest in IR-case $1(7.3-8.0)$. The stabilization of $\mathrm{pH}$ in IR-cases 1,2 and 3 occurred at ca. PV 4, 10 and 20, respectively. These PVs corresponded to ca. 20 weeks even if the infiltration rates were different (Figures 3(a) and 3(b)). The Eh in all 3 cases were variable (range: $+0.27-+0.47 \mathrm{~V}$ ), but remained under oxidizing conditions throughout the duration of the experiment (Figure 3(c)). Figure 3(d) illustrates the leaching behavior of As in the columns under varying infiltration rates. 
The leaching curves of As had distinct peaks showing a generally increasing height and width with increasing infiltration rate. IR-case 3 (with the highest infiltration rate) had the highest and widest As concentration peak ( $300 \mu \mathrm{g} / \mathrm{L} ; 20 \mathrm{PV}$ ) among the three cases. Although the concentrations of As in the effluent changed over time, it stabilized after ca. 12 and $20 \mathrm{PV}$ in cases 2 and 3, respectively. These PVs were achieved after ca. 20 weeks in both cases.

The EC of the effluents collected was also monitored throughout the duration of the experiment. The EC gives us a general idea about the concentrations of major coexisting ions present in the solution. Figures 3(e), 3(f) and 3(g) illustrate the evolution of $\mathrm{EC}, \mathrm{Ca}^{2+}$ and $\mathrm{SO}_{4}{ }^{2-}$ concentrations in the effluents of IR-cases 1, 2 and 3. In all three cases, the first effluents collected had the highest $\mathrm{EC}$ values and contained the highest concentrations of $\mathrm{Ca}^{2+}$ and $\mathrm{SO}_{4}{ }^{2-}$. These values decreased dramatically and leveled off after 2 PV (Figures 3(e), 3(f) and 3(g)). After the rapid concentration decrease, peaks of $\mathrm{Ca}^{2+}$ and $\mathrm{SO}_{4}{ }^{2-}$ curves were observed in IR-cases 1 and 2 around PV 5 and 10 but not in IR-case 3. Most of the Fe concentrations of the effluents were below $0.001 \mathrm{mg} / \mathrm{L}$ (ICP-AES + ultrasonic generator detection limit) except for two effluent samples of IR-case 3 during the early part of the experiment (Figure 3(h)).

\subsubsection{Bulk density}

BD-cases 1 and 2 represent columns with and without compaction, respectively as shown in Figure 4. A lower bulk density resulted in longer water residence time in the column (Figure 4(a)). It took ca. a week longer to collect $1 \mathrm{PV}$ in BD-case 2 than in BD-case 1 . The $\mathrm{pH}$ of the column with higher bulk density was initially higher but after PV 8, the trends were reversed. However, the Eh values did not dramatically change with variations in the bulk density of the columns and remained under oxidizing conditions (Figure 4(c)). In both cases, peaks were 
observed in the leaching curves of As, but the peak in BD-case 1 was more than twice as high $(125 \mu \mathrm{g} / \mathrm{L})$ as that of BD-case $2(58.4 \mu \mathrm{g} / \mathrm{L})($ Figure $4(\mathrm{~d}))$.

The EC, $\mathrm{Ca}^{2+}$ and $\mathrm{SO}_{4}{ }^{2-}$ concentrations in $\mathrm{BD}$-cases 1 and 2 were similar to each other as displayed in Figures 4(e), 4(f) and 4(g). The initial EC values of the effluents as well as the concentrations of $\mathrm{Ca}^{2+}$ and $\mathrm{SO}_{4}{ }^{2-}$ were quite similar in the two cases. Also, initially high EC, $\mathrm{Ca}^{2+}$ and $\mathrm{SO}_{4}{ }^{2-}$ concentrations decreased rapidly until PV 2 in both cases. The peak in the $\mathrm{Ca}^{2+}$ and $\mathrm{SO}_{4}{ }^{2-}$ curves was also more pronounced and appeared earlier in BD-case 2. Concentrations of Fe in the effluents were all below $0.001 \mathrm{mg} / \mathrm{L}$ irrespective of the bulk density (Figure 4(h)).

\subsubsection{Rock bed thickness}

The water residence time was also affected by the rock bed thickness as displayed in Figure 5(a). RT-case 3 (thickest rock bed) had the longest water residence time among the three cases. The $\mathrm{pH}$ and As concentration also depended on the rock bed thickness while the Eh values were similar in the 3 cases as illustrated in Figure 5. Column with the thinnest rock bed (RT-case 1) had the highest effluent $\mathrm{pH}$ range (7.6 - 9.2) especially during the first $20 \mathrm{PV}$ (Figure 5(b)). After this, the $\mathrm{pH}$ values of the 3 cases were similar to each other. The Eh values in RT-cases 1, 2 and 3 fluctuated but remained in the oxidizing region throughout the duration of the experiments (Figure 5(c)). Peaks in the concentration curve of As with time decreased with increasing rock bed thickness (Figure 5(d)). The peak in RT-case 1 was also wider (ca. 20 PV) than those of RT-case 2 (ca. 10 PV) and RT-case 3 (ca. 6 PV).

Figures 5(e), 5(f) and 5(g) show the changes in $\mathrm{EC}, \mathrm{Ca}^{2+}$ and $\mathrm{SO}_{4}{ }^{2-}$ concentrations with variations in the rock bed thickness. Similar to the other cases discussed earlier, the concentrations of $\mathrm{Ca}^{2+}$ and $\mathrm{SO}_{4}{ }^{2-}$ coincided with the $\mathrm{EC}$ curves even if the rock bed thicknesses were different. The highest EC, $\mathrm{Ca}^{2+}$ and $\mathrm{SO}_{4}{ }^{2-}$ in all three cases were observed at the start of the 
experiments and then decreased rapidly until PV 2. Peaks in the $\mathrm{Ca}^{2+}$ and $\mathrm{SO}_{4}{ }^{2-}$ curves appeared only in RT-cases 2 and 3, but not in RT-case 1. Similar to the cases with varying infiltration rates, most of the effluent samples in the cases with varying rock bed thicknesses had $\mathrm{Fe}$ concentrations less than $0.001 \mathrm{mg} / \mathrm{L}$ except for nine effluent samples collected from RT-case 1 , which had the shortest water residence (Figure 5(h)).

Figure 6 illustrates the relationship of $\mathrm{Ca}^{2+}$ and As in the effluents. Concentrations of $\mathrm{Ca}^{2+}$ greater than ca. $50 \mathrm{mg} / \mathrm{L}$ apparently reduced the concentration of As in the effluent irrespective of the infiltration rate, bulk density and the rock bed thickness.

Results of the tracer and spike tests after 76 weeks are summarized in Figure 7. The tracer tests demonstrate that water flow was not facilitated by channeling although dispersion was significant in all three cases. Also, the breakthrough curves of $\mathrm{Br}^{-}$indicate that chemical species in the effluent of RT-case 1 have the shortest residence time as compared to RT-cases 2 and 3. Spiked As concentrations were approximately 200 times more than the concentration of As in the effluent of the three cases at that time. A peak in the concentration curve of As due to the spike test was only observed in RT-case 1 , but not in the other cases. The peak was only ca. $80 \mu \mathrm{g} / \mathrm{L}$, which corresponded to ca. $0.8 \%$ of the total amount of As spiked into this column. Also, this peak appeared 8 weeks after the addition of the spike and 5 weeks after most of the tracers left the column. Ten weeks after the spike and tracer tests, the infiltration rates in RT-cases 2 and 3 were increased 3.5 times and resulted in a slight increase in the concentration of As in the effluent (Figure 7). This As increase in the effluent of RT-cases 2 and 3 approached the concentration of As in RT-case 1 (Figure 7(b)). 


\subsubsection{Speciation of As}

Actual measurements of As[III] and As[V] concentrations in the effluent shown in Figure 8 illustrate a complex relationship between these two species. In all four cases shown, several concentration peaks of As[III] and As[V] were observed during the first 30 weeks of the experiment. Variations in the rock bed thickness also changed the speciation of As in the effluent as shown in Figure 8(a), (c) and (d). In RT-case 1, As[III] was the dominant As species at the initial stage of the experiment but in RT-case 2 and 3, the major As species was As[V]. Arsenic[V] peaks coincided with the total As concentration peaks during the early stages of the experiment. Also, As[V] was the dominant species in the effluents of all four cases after week 30.

\subsection{Spatial variability in columns after the experiment}

\subsubsection{Solid phase comparison to starting conditions}

Figure 9 illustrates the changes that occurred on the four important As-bearing fractions of the rock with depth (IR case 3). All four fractions showed similar As content variations after the experiment, that is, the amount of As was lower at the top and higher around the middle and bottom part of the column than the initial As content of the rock. Among these four fractions, the As content found in the exchangeable and oxidizable fractions were higher by as much as 0.93 and $20.8 \mathrm{mg} / \mathrm{kg}$, respectively, and accounted for most of the As content variation in the middle and bottom part of the column. In contrast, the As content of solid phases at the top of the column were lower than the initial As content by as much as $0.13,0.43$ and $1.2 \mathrm{mg} / \mathrm{kg}$ for the carbonate, exchangeable and oxidizable fractions, respectively. 


\subsubsection{Water distribution}

Figure 10(a) illustrates the distribution of volumetric water content with depth in RT-cases 1, 2 and 3. These three cases were unsaturated overall (average volumetric water content: $0.31-0.32$ $\mathrm{cm}^{3} / \mathrm{cm}^{3}$ ), but because water was allowed to flow through the columns by gravity, the water content with depth was not uniform. At the topmost part of the column, volumetric water content in RT-cases $2\left(0.27 \mathrm{~cm}^{3} / \mathrm{cm}^{3}\right)$ and $3\left(0.26 \mathrm{~cm}^{3} / \mathrm{cm}^{3}\right)$ were similar while that of RT-case 1 was

somewhat higher $\left(0.31 \mathrm{~cm}^{3} / \mathrm{cm}^{3}\right)$. These values increased with depth reaching values close to saturation at the bottom of the columns (range: $0.36-0.37 \mathrm{~cm}^{3} / \mathrm{cm}^{3}$ ). In all cases, nearly saturated conditions were only observed at the bottom part of the columns $(88-90 \%)$ while the upper parts were unsaturated $(61-76 \%)$.

\subsubsection{Arsenic concentration and speciation in pore waters}

The distributions of As in the pore water with depth in RT-cases 1,2 and 3 are illustrated in Figure 10(b). In RT-case 1, the concentration of As was $72 \mu \mathrm{g} / \mathrm{L}$ at the top, reaching a maximum concentration around the middle of the column followed by a decrease in the concentration at the bottom. This trend of As concentration increase followed by a decrease with depth was also observed in the other 2 cases. In RT-cases 2 and 3, As concentrations of pore water around the top of the column were close to each other, but were lower than RT-case 1. The maximum As concentrations were observed at depths of ca. $120 \mathrm{~mm}(98.8 \mu \mathrm{g} / \mathrm{L})$ and $70 \mathrm{~mm}(102 \mu \mathrm{g} / \mathrm{L})$ for RT-cases 2 and 3, respectively. At the bottom of the columns, the concentration of As in RT-case 2 was slightly higher than RT-case 3 . Among these 3 cases, the pore water collected from RTcase 1 had the highest concentration peak of As.

The speciation of As with depth was only done in RT-case 1 as displayed in Figure 11. We chose only RT-case 1 for the speciation analysis because it was the column where the infiltration 
rate was not changed until the end of the experiment. As noted earlier, the higher infiltration rate increased the concentration of As in the effluent and might also alter the distribution of As species. Arsenic[III] was measured in the pore water close to the middle of the column at $33 \%$ $(40.4 \mu \mathrm{g} / \mathrm{L})$ of the total As concentration. However, As[V] was the dominant As species in the pore water irrespective of the depth.

\section{DISCUSSION}

\subsection{Sources of As in the altered rock sample}

The sample taken from the bulk excavated rock has As content greater than twice the average As content of sedimentary rocks (average As content of sedimentary rocks is in the range of $5-10$ ppm (Webster, 1999)). This higher As abundance is due to the hydrothermal alteration of the rock (Takahashi et al., 2011). Although the amount of pyrite was diluted by the unaltered rock that was also excavated, our sequential extraction results still point to the oxidizable fraction (i.e., sulfides and organic matter) as the primary source of As in the rock. Also, most of the exchangeable As fraction probably originates from the partial oxidation of pyrite during the excavation, transport and storage of the bulk rock prior to sampling. Pyrite oxidation starts rapidly upon exposure to the atmosphere, commencing with the oxidation of $S^{2-}$ species (Schaufuss et al., 1998). This process is enhanced further in the presence of water or moisture that could strip reaction products on the pyrite surface exposing "fresh" sites for further oxidation. Atmospheric oxidation of pyrite leads to the formation of Fe sulfate, Fe oxyhydroxides and oxides (de Donato et al., 1993; Schaufuss et al., 1998; Todd et al., 2003). Based on these results, pyrite can be an important source of As in altered rocks and should be suspected as a possible source of As even if it is only found in trace amounts. 


\subsection{Water residence time and solution composition}

Variations in the infiltration rate, bulk density and rock bed thickness had similar effects on the $\mathrm{pH}$ and As leaching trends observed in the effluents because these parameters could affect the water residence time in identical fashions. Shorter water residence time at higher infiltration rate or thinner rock bed resulted in higher As concentrations in the effluent (Figures 3 and 5). Even small differences in the water residence time had a significant effect on the As concentration of the effluent (Figure 4). Higher As concentrations were also observed to coincide with higher $\mathrm{pH}$ values, which indicates that $\mathrm{pH}$ is important in the mobilization of As even under column conditions with small $\mathrm{pH}$ variations. On the other hand, $\mathrm{Ca}^{2+}$ and $\mathrm{SO}_{4}{ }^{2-}$, sourced from calcite and pyrite, respectively had been "flushed-out" from the rock in all cases at PV 2 independent of the water residence time. Geochemical modeling calculations show that precipitation of gypsum was only thermodynamically possible during the first couple of weeks because of the high concentrations of $\mathrm{Ca}^{2+}$ and $\mathrm{SO}_{4}{ }^{2-}$ in the effluent (Figure 12). Dissolution of precipitated gypsum later on in the experiment could be responsible for the appearance of $\mathrm{Ca}^{2+}$ and $\mathrm{SO}_{4}{ }^{2-}$ concentration peaks after their rapid decrease (Figures 3, 4, 5 and 12). However, these peaks were only observed in cases with lower amount of water addition. These results suggest that the leaching of conservative ions like $\mathrm{Ca}^{2+}$ and $\mathrm{SO}_{4}{ }^{2-}$ was independent of the water residence time and was probably affected more by dilution.

Calcium arsenates including its hydrated forms, are relatively stable in a wide range of $\mathrm{pH}$ (3 - 12.5) and could effectively immobilize dissolved As when precipitated (Bothe and Brown, 1999; Zhu et al., 2006). However, precipitation of calcium arsenates was not possible even though concentrations of $\mathrm{Ca}^{2+}$ were greater than $500 \mathrm{mg} / \mathrm{L}$ at the start of the experiment. In contrast, precipitation of Al-oxides/oxyhydroxides like gibbsite $\left(\mathrm{Al}(\mathrm{OH})_{3}\right)$ and boehmite 
$(\mathrm{AlOOH})$ were thermodynamically favorable (Figure 12). Very low concentration of $\mathrm{Fe}$ in the effluent could be an indicator of the precipitation of Fe-oxyhydroxides/oxides in the column (Figures 3, 4 and 5). In several effluents with Fe concentrations greater than $0.001 \mathrm{mg} / \mathrm{L}$, the $S I$ values of Fe-oxyhydroxides/oxides like $\mathrm{Fe}(\mathrm{OH})_{3}$ and lepidocrocite $(\mathrm{FeOOH})$ were greater than zero, which means that the pore water is supersaturated with respect to these minerals and they should precipitate under the $\mathrm{pH}$ and Eh conditions in the columns. These results support our earlier deduction of Fe-oxyhydroxides/oxides precipitation in the columns. Also, concentrations of Fe in the effluent greater than $0.001 \mathrm{mg} / \mathrm{L}$ were only observed in IR-case 3 and RT-case 1 that had short water residence times (Figures 3 and 5). This indicates that shorter water residence time at higher infiltration rate or thinner rock bed limits the extent of Fe-oxyhydroxide/oxide precipitation in the columns. Based on these results, water residence time influenced the release of As by controlling the $\mathrm{pH}$ and the extent of Fe-oxyhydroxides/oxides precipitation.

Major coexisting ions that could influence the adsorption of As such as $\mathrm{Ca}^{2+}$ and $\mathrm{SO}_{4}{ }^{2-}$, are also important in As mobilization from the altered rock. Regardless of the variations in the infiltration rate, bulk density and rock bed thickness, all cases showed the same effect of $\mathrm{Ca}^{2+}$ ion on As leaching, that is, the release of As was retarded in the presence of $\mathrm{Ca}^{2+}$ ions in excess of ca. $50 \mathrm{mg} / \mathrm{L}$ (Figure 6). This could be attributed to the ability of $\mathrm{Ca}^{2+}$ ions to increase the positive charge on an oxide layer and/or create more positive surfaces (Ghosh and Teoh, 1985; Meng et al., 2000; Wilkie and Herring, 1996). According to Jeong et al. (2007), high $\mathrm{SO}_{4}{ }^{2-}$ in excess of $250 \mathrm{mg} / \mathrm{L}$ has a moderate negative effect on the adsorption of As onto Fe-oxides and Al-oxides, but even though the concentration of $\mathrm{SO}_{4}{ }^{2-}$ in the effluent during the first weeks of the experiments were greater than $3,000 \mathrm{mg} / \mathrm{L}$, this negative effect was not observed. Thus, when both ions are present in solution at relatively high concentrations, the positive effect of $\mathrm{Ca}^{2+}$ 
appears to outweigh the negative effect of $\mathrm{SO}_{4}{ }^{2-}$ especially under oxic and slightly alkaline $\mathrm{pH}$ conditions.

\subsection{Mineral dissolution, pyrite oxidation, precipitation and $\mathrm{pH}$ variability}

Understanding the processes controlling the $\mathrm{pH}$ is of utmost importance because of its strong influence on the leaching of As from hydrothermally altered rocks. The $\mathrm{pH}$ of a rock-water system is governed by complex chemical and mineralogical interactions. For example, rocks with sulfide minerals like pyrite have acidic $\mathrm{pH}$ when in contact with water due to pyrite oxidation while those with sufficient carbonate minerals like calcite have slightly alkaline $\mathrm{pH}$. Carbonate dissolution and pyrite oxidation are complex processes that have been the subjects of extensive studies (Appelo and Postma, 2005; Chandra and Gerson, 2010; Evangelou, 1995; Plummer et al., 1978; Rimstidt and Vaughan, 2003). In this study, the $\mathrm{pH}$ of the effluents is controlled by mineral dissolution, pyrite oxidation, and precipitation and hydrolysis reactions. The altered rock contained significant quantities of calcite, and its dissolution released bicarbonate ions into solution causing the observed alkaline $\mathrm{pH}$ of the effluent. However, calcite is not the only mineral responsible for the observed $\mathrm{pH}$ in the columns. Pyrite also influences the $\mathrm{pH}$ by means of three related processes. First, aqueous pyrite oxidation by dissolved oxygen produces acidity according to the following reactions:

$$
\begin{array}{lll}
\mathrm{FeS}_{2(\mathrm{~s})}+15 / 4 \mathrm{O}_{2(\mathrm{~g})}+5 / 2 \mathrm{H}_{2} \mathrm{O} & \rightarrow \mathrm{FeOOH}_{(\mathrm{s})}+4 \mathrm{H}^{+}+2 \mathrm{SO}_{4}{ }^{2-} & \text { Equation 1 } \\
2 \mathrm{FeS}_{2(\mathrm{~s})}+15 / 2 \mathrm{O}_{2(\mathrm{~g})}+4 \mathrm{H}_{2} \mathrm{O} & \rightarrow \mathrm{Fe}_{2} \mathrm{O}_{3(\mathrm{~s})}+8 \mathrm{H}^{+}+4 \mathrm{SO}_{4}{ }^{2-} & \text { Equation 2 } \\
\mathrm{FeS}_{2(\mathrm{~s})}+15 / 4 \mathrm{O}_{2(\mathrm{~g})}+7 / 2 \mathrm{H}_{2} \mathrm{O} & \rightarrow \mathrm{Fe}(\mathrm{OH})_{3(\mathrm{~s})}+4 \mathrm{H}^{+}+2 \mathrm{SO}_{4}{ }^{2-} & \text { Equation 3 }
\end{array}
$$

Second, atmospheric oxidation of pyrite produces sulfuric acid $\left(\mathrm{H}_{2} \mathrm{SO}_{4}\right)$ on the exposed pyrite surface because of the hygroscopic nature of $\mathrm{Fe}^{2+}$ sulfate (Chandra and Gerson, 2010; Jerz and 
Rimstidt, 2004). Third, the $\mathrm{pH}$ of the rock-water system is further influenced by Feoxyhydroxide/oxide precipitation and hydrolysis according to the following equations:

$$
\begin{array}{ll}
\mathrm{Fe}^{2+}+1 / 4 \mathrm{O}_{2(\mathrm{aq})}+21 / 2 \mathrm{H}_{2} \mathrm{O} \rightarrow \mathrm{Fe}(\mathrm{OH})_{3}+2 \mathrm{H}^{+} & \text {Equation } 4 \\
\mathrm{Fe}^{2+}+2 \mathrm{H}_{2} \mathrm{O} \rightarrow \mathrm{Fe}(\mathrm{OH})_{2}+2 \mathrm{H}^{+} & \text {Equation 5 }
\end{array}
$$

Precipitation of dissolved $\mathrm{Fe}$ as iron oxides and hydroxides results in the production of $\mathrm{H}^{+}$ increasing the acidity of the effluent. Pyrite oxidation and the subsequent precipitation of Feoxyhydroxides should have caused the initial $\mathrm{pH}$ in the columns to be acidic but the abundant calcite in the rock effectively neutralized this acidity resulting in a slightly alkaline $\mathrm{pH}$ of the rock. This neutralization reaction is supported by the similar leaching curves of $\mathrm{Ca}^{2+}$ and $\mathrm{SO}_{4}{ }^{2-}$ in the effluent even at the onset of the experiments (Figures 3, 4 and 5).

Consistently higher $\mathrm{pH}$ values were also observed in the effluents of cases with shorter water residence time during the first 20 weeks of the experiment, which could be attributed to dissolved $\mathrm{O}_{2}$ and $\mathrm{CO}_{2}$. Oxygen is important in pyrite oxidation and Fe-oxyhydroxide/oxide precipitation while $\mathrm{CO}_{2}$ controls the nature of calcite dissolution (i.e., whether open or closed system type). This is of particular importance in our experiments because the deionized water used was taken directly from the Millipore Milli-Rx $12 \alpha$ system that produced ultra pure water

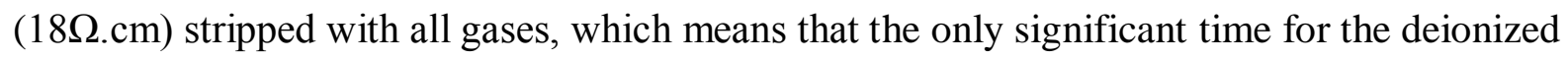
water to be in contact with atmospheric gases was during the column experiments.

Geochemical simulation of an ideal system containing pyrite and calcite showed that the $\mathrm{pH}$ was indeed a function of dissolved $\mathrm{CO}_{2}$ and $\mathrm{O}_{2}$ (Table 6). In order to achieve the slightly alkaline $\mathrm{pH}$ of the column effluents, the $\mathrm{CO}_{2}$ concentration $(\mathrm{mg} / \mathrm{L})$ must be very low and the $\mathrm{O}_{2}$ concentration should be ca. $5 \mathrm{mg} / \mathrm{L}$ (Table 6). Thus, for a calcite-pyrite system to have a slightly alkaline $\mathrm{pH}$, calcite dissolution must approach a "closed" system type with respect to $\mathrm{CO}_{2}$ and 
the $\mathrm{O}_{2}$ concentration in the pore water should be less than saturation with respect to atmospheric $\mathrm{O}_{2}$. Because of the $\mathrm{CO}_{2}$-free deionized water used in the column experiments as well as the relatively slow dissolution of $\mathrm{CO}_{2}$ into water especially under ambient conditions with low partial pressure of $\mathrm{CO}_{2}\left(P_{\mathrm{CO} 2} \leq 10^{-3.5}\right.$ atm) (Liu and Dreybrodt, 1997), the rate of consumption of dissolved $\mathrm{CO}_{2}$ in the pore water during calcite dissolution was faster than the rate at which it was replenished, resulting in a closed system type. The importance of dissolved $\mathrm{CO}_{2}$ on the evolution of $\mathrm{pH}$ in an actual field setting (i.e., a mine pit lake in contact with altered rocks) was also pointed out by Savage et al. (2009). In addition, lower $\mathrm{pH}$ in columns with longer water residence time could be attributed to higher concentration of dissolved $\mathrm{O}_{2}$ in the pore water that could increase pyrite oxidation leading to the generation of more acidity in the rock-water system.

Our results indicate that the evolution of $\mathrm{pH}$ with time in the columns could be divided into two distinct stages: stage 1 (weeks 1 -20) with a peak in the $\mathrm{pH}$ curve, and stage 2 (weeks > 20) where the $\mathrm{pH}$ stabilized. In stage 1 , the variations in the $\mathrm{pH}$ were the result of the combined effects of the dissolution of calcite and other soluble mineral phases, pyrite oxidation and Feoxyhydroxide/oxide precipitation. At this stage, Fe-oxyhydroxide/oxide precipitation is more pronounced because of the presence of secondary soluble products from atmospheric pyrite oxidation like Fe(II)-sulfate. This deduction is consistent with the observed lower pH values in cases with longer water residence time and the very low concentrations of Fe in the effluent (Figures 3, 4 and 5). On the other hand, the nearly constant $\mathrm{pH}$ observed in stage 2 could be attributed to the combined effects of pyrite oxidation and calcite dissolution. 


\subsection{Mechanisms of As release}

The mobilization of As from the hydrothermally altered rock with time also occurred in two stages, which coincided with the stages in the evolution of $\mathrm{pH}$ discussed above. Stage 1 (week 1 - 20) was characterized by strong fluctuations in the $\mathrm{pH}$ and $\mathrm{Eh}$, decreasing $\mathrm{Ca}^{2+}$ and $\mathrm{SO}_{4}{ }^{2-}$ concentrations and As concentration peaks in the effluent (Figure 3, 5 and 7). On the other hand, stage 2 (after week 20) had a more stable $\mathrm{pH}, \mathrm{Eh}, \mathrm{As}, \mathrm{Ca}^{2+}$ and $\mathrm{SO}_{4}{ }^{2-}$ concentrations in the effluent (Figure 3, 5 and 7). This means that the processes controlling the evolution of $\mathrm{pH}$ and the mobilization of As from hydrothermally altered rock are similar. The mobilization of As during stage 1 results from the combined effects of the dissolution of soluble As-bearing phases like $\mathrm{Fe}(\mathrm{II})$-sulfates and aqueous pyrite oxidation. The relatively high concentration of $\mathrm{SO}_{4}{ }^{2-}$ in the effluent at the start of the experiment and its "flushing-out" leaching curve are strong indications of the presence of these soluble phases containing As most likely formed during the exposure of the rock prior to sampling (Figures 3, 4 and 5). In stage 2, the mobilization of As could be attributed to the continued oxidation of pyrite in the presence of calcite. Continued pyrite oxidation after stage 1 is also supported by our geochemical modeling calculations using PHREEQC (Table 6). In this simulation consisting of an ideal system of pyrite and calcite, the calculated concentrations of $\mathrm{Ca}^{2+}$ and $\mathrm{SO}_{4}{ }^{2-}$ as well as the $\mathrm{pH}$ agreed well with the experimental results especially those of RT-case 3 . This means that in the long run, pyrite oxidation and calcite dissolution are the processes that would control the $\mathrm{pH}, \mathrm{As}, \mathrm{Ca}^{2+}$ and $\mathrm{SO}_{4}{ }^{2-}$ concentrations of the effluent.

Dissolved Fe from pyrite oxidation and the dissolution of soluble oxidation products like Fesulfates would also precipitate under the alkaline $\mathrm{pH}$ conditions encountered in the columns. This deduction is supported by very low concentrations of Fe in the columns $(<0.001 \mathrm{mg} / \mathrm{L})$ in 
comparison to batch experiments $(0.30 \mathrm{mg} / \mathrm{L})$. Our PHREEQC modeling calculations also predicted the formation of Al-oxyhydroxides/oxides in addition to the precipitation of $\mathrm{Fe}$ oxyhydroxides/oxides (Figure 12). These precipitates have strong adsorption affinities for oxyanions and have primary roles in As immobilization when present in a system. Also, the altered rock contains clay minerals like kaolinite that could adsorb As. Adsorption of As onto Fe and $\mathrm{Al}$ oxides/oxyhydroxides as well as clay minerals has been reported by many authors (Cornelis et al., 2008; Dousova et al., 2003; Dzombak and Morel, 1990; Gosh and Teoh, 1985; Lin and Puls, 2000; Wang and Mulligan, 2006). Moreover, As concentrations in the effluent did not increase even after the addition of As[III] and As[V] (Figure 7). Based on these results, since Fe and $\mathrm{Al}$ oxyhydroxide/oxide precipitates as well as clay minerals are present in the columns, a portion of the released As is also immobilized through adsorption onto these precipitates and/or minerals. Also, adsorbed As in the column was stable even after the introduction of additional As loadings and a three-folds increase in the infiltration rate (Figure 7). Increasing the infiltration rate resulted in slight but gradual increase in the amount of As released from the rock and reduced the water residence time. This gradual increase in As leaching indicates that the system is undergoing an equilibrium shift brought about by the higher amount of water added into the columns.

Similar trends in the As concentrations of the pore water and effluents of columns with different rock bed thickness illustrate the presence of two regions that influences the movement of As with depth. The first region is found at the top half while the second region is located in the bottom half of the column. Leaching of As predominantly occurred at the upper part of the column probably because of the high $\mathrm{pH}$ and low concentrations of As and other ions in the pore water. This deduction is supported by the high As concentrations of the pore water at a depth of 
$100 \mathrm{~mm}$. As the As-laden pore water travels further down the second half of the column, the saturation of ions like $\mathrm{Ca}^{2+}, \mathrm{Al}$ and $\mathrm{Fe}$ increases, resulting in the precipitation of carbonates and $\mathrm{Fe}$ and/or $\mathrm{Al}$ oxyhydroxides/oxides. This explanation is also in agreement with the $\mathrm{Fe}$ concentrations of the effluent samples collected at 100, 200 and $250 \mathrm{~mm}$. Existence of leaching and immobilization regions in the columns is further supported by the sequential extraction results with depth (Figure 9). The amount of As associated with oxidizable (i.e., sulfides and organic matter), exchangeable and carbonate fraction decreased in the upper part of the column. In contrast, the amount of As associated in these fractions increased at the bottom half of the column. Sulfides like pyrite and organic matter could both act as adsorbents of As. Adsorption of As species especially As[III] onto pyrite could form "arsenopyrite-like” surface precipitates (Bostick and Fendorf, 2003) while humic acids (HA) that are only soluble under strongly alkaline conditions could exist in the solid phase or as coatings on mineral surfaces, which tends to enhance As adsorption and immobilization (Stollenwerk, 2003). Thus, As is released at the upper part of the column by desorption of exchangeable phases, dissolution of carbonates and oxidation of pyrite while in the bottom part, As is immobilized by adsorption processes onto sulfides, carbonates, organic matter and Fe-oxyhydroxides/oxides.

\subsection{Mechanisms of As speciation}

Figure 13 is an Eh - pH diagram constructed using The Geochemist's Workbench ${ }^{\circledR}$, which illustrates the $\mathrm{pH}$ and Eh dependence of As species. The parameters used were based on the actual effluent chemistry collected from the columns (activity of As $=10^{-6}$; activity of $\mathrm{SO}_{4}{ }^{2-}=$

$10^{-3}$ ). Regions where the effluents of all cases are located based on their measured $\mathrm{pH}$ and $\mathrm{Eh}$ are also illustrated in the diagram. The Eh $-\mathrm{pH}$ diagram predicts that the major As species in the effluents would be $\mathrm{HAsO}_{4}{ }^{2-}$, which is an oxyanion of As[V]. The speciation of As predicted by 
the geochemical model was consistent with the measured As speciation during our batch experiments that are close to equilibrium conditions (Figures 2 and 13). Although the geochemical model failed to predict the speciation under column laboratory conditions especially during the first 30 weeks of the experiment, it was able to predict speciation of As after week 30 . Shortcomings of the $\mathrm{Eh}-\mathrm{pH}$ diagram could be attributed to the lack of equilibrium between different redox couples in the effluents collected. Under disequilibrium conditions, Eh is a poor predictor of speciation of trace elements like As (Appelo and Postma, 2005). None the less, speciation of As was predicted by the $\mathrm{Eh}-\mathrm{pH}$ diagram especially in the long run; that is of importance during the actual disposal of the rock. Another interesting point that should be noted in these results is that the observed fluctuations in As[III] and As[V] concentrations happened only during the first 30 weeks of the experiment, corresponding to stage 1 of As mobilization with time discussed earlier. These suggest that the speciation of As in the effluent is strongly affected by the $\mathrm{pH}$, dissolution of soluble secondary minerals of pyrite, coexisting ions and $\mathrm{Fe}$ oxyhydroxide/oxide precipitation.

Results of As speciation measurements with depth illustrates that As[V] was the dominant species in the column. However, substantial amounts of As[III] was found around the middle where the highest total As concentration was observed. These pore water samples were taken at the end of the experiment when the columns had already reached steady state. Around this time, the effluent As concentration was predominantly As[V]. The disappearance of As[III] at the bottom of the column suggests its oxidation as it moves down the column. There are two probable ways for the oxidation of As[III] to As[V] to occur. First, the presence of organic matter and Mn oxyhydroxides in the rock could effectively oxidize As[III] to As[V] (Chiu and Hering, 2000; Redman et al., 2002). Redman et al. (2002) observed that natural organic matter 
(NOM) was capable of both reducing As[V] to As[III] and oxidizing As[III] to As[V].

According to the authors, NOM structures themselves were the most likely redox-active agents influencing arsenic speciation, acting by means of quinone or other functional groups that had been previously oxidized or reduced in their native environments. Second, under low As concentrations, As[III] could undergo oxidation in the presence of As[V] (Jang and Dempsey, 2007). Conversion of As[III] to As[V] decreases the mobility of As by adsorption, which results in the immobilization of additional As loadings in the columns.

We have observed two important points regarding the mobilities of As[III] and As[V] based on the results of our batch and column experiments. First, the appearance of As[III] and As[V] concentration peaks indicates a somewhat "seesaw"-like relationship between these species. Second, the altered rock has the ability to attenuate As[III] generally regarded as more mobile than As[V]. The "seesaw"-like behavior of As[III] and As[V] could be attributed to the combined effects of $\mathrm{pH}$ and $\mathrm{Ca}^{2+}$ ion on the adsorption of these two species. Arsenic[III] was the dominant species in the effluent collected at the start of the experiment (ca. week 5) in cases with shorter water residence time and lower $\mathrm{pH}(\mathrm{ca} . \mathrm{pH}$ ) $)$ and high concentrations of $\mathrm{Ca}^{2+}(>50$ $\mathrm{mg} / \mathrm{L}$ ). The slightly lower $\mathrm{pH}$ coupled with the high $\mathrm{Ca}^{2+}$ concentration could effectively increase the positive charges on mineral surfaces of the rock that could result in the preferential adsorption of the charged $\mathrm{As}[\mathrm{V}]$ oxyanion $\left(\mathrm{HAsO}_{4}{ }^{2-}\right.$ ) in comparison to the uncharged $\mathrm{As}[\mathrm{III}]$ oxyanion $\left(\mathrm{H}_{3} \mathrm{AsO}_{3}\right)$. As the $\mathrm{pH}$ increased to around 9 and the $\mathrm{Ca}^{2+}$ concentration decreased below $50 \mathrm{mg} / \mathrm{L}$, the degree of desorption of $\mathrm{As}[\mathrm{V}]$ oxyanions increased because of the formation of more negatively charged surfaces while As[III] oxyanions were preferentially adsorbed on the mineral surfaces especially onto those of Fe-oxyhydroxides, which resulted in the increased $\mathrm{As}[\mathrm{V}]$ concentration in the effluent. The next dominant As species inversion happened around 
the time of the $\mathrm{pH}$ decrease. At this point, desorption of As[III] and adsorption of As[V] may have happened because of the change in the adsorption preference of Fe-oxyhydroxides from $\mathrm{As}[\mathrm{III}]$ to $\mathrm{As}[\mathrm{V}]$. In addition, more positive surfaces are generated with decreasing $\mathrm{pH}$, favoring the adsorption of the charged As[V] oxyanion. These changes may result in the leaching of more As[III] from the rock, making it the most dominant species in the effluent at this point. Finally, the last concentration inversion seems to indicate apparent steady state conditions in the column with As[V] being the dominant species consistent with our batch leaching results and predictions of the $\mathrm{Eh}-\mathrm{pH}$ diagram. These results were also consistent with the observed As adsorption characteristics on ferrihydrite (Fe-oxyhydroxide) of As[III] and As[V] with pH (Raven et al., 1998). Raven et al. (1998) illustrated that at low total dissolved As concentrations, As[III] was preferentially adsorbed onto ferrihydrite at higher $\mathrm{pH}(8-9.5)$ while As[V] was favorably adsorbed at lower $\mathrm{pH}(4.2-7.5)$. These results indicate that $\mathrm{pH}$-dependent adsorption of As species is an important mechanism affecting the mobilization and speciation of As from these rocks. Moreover, this mechanism may be important in aquifers with slightly alkaline $\mathrm{pH}$ containing sulfide-bearing sediments or with high dissolved Fe concentrations where As release is accompanied by the precipitation of Fe-oxyhydroxides/oxides.

\subsection{Engineering implications}

Results of this study identified the important mechanisms of As speciation and release from hydrothermally altered rock under column conditions. Identification of these mechanisms is an essential preliminary step in the design of an alternative disposal method to minimize the release of contaminants like As from these kinds of rocks to the environment. From our results, we found that controlling the water residence time is essential in the success of any engineered 
countermeasures for these rocks. The water residence time can be controlled by variations in the infiltration rate, rock bed thickness or bulk density.

Aside from the water residence time, particle size distribution is also an important parameter but was not included in this study. Differences in the particle size distribution of rocks used in the laboratory experiment and the actual disposal may have strong influence on the mechanisms of As release as well as the $\mathrm{pH}$ of the system. However, the As and $\mathrm{pH}$ trends observed in the column experiments were identical to those reported in our earlier paper under in situ conditions that utilized the actual size distribution of the excavated rock (Tabelin et al., 2010). The release of As and the evolution of $\mathrm{pH}$ were also controlled by pyrite oxidation, calcite dissolution and Fe-oxyhydroxide/oxide precipitation (Tabelin et al., 2010). During the in situ experiment, the concentration of As in the pore water at the top was consistently lower that the middle part of the impoundment, which is identical to the spatial distribution of As discussed in section 3.4.1. But the first stage (Stage 1) in the evolution of $\mathrm{pH}$ and As release was not apparent in the in situ experiments because of the difficulties of collecting pore water samples. Our results also showed that using the finer particle size in the column experiments resulted in higher concentration of As in the pore water. These indicate that the finer size distribution used in this study have higher reactivity than the actual waste rock and could be used as the "ceiling" with respect to the estimation of the quantity of As mobilized from the rock.

Finally, we have observed that a thicker rock bed would minimize As mobilization by decreasing the water residence time and enhancing Fe-oxyhydroxide/oxide precipitation and adsorption. The thickness of the rock bed during the actual disposal would be greater by one or two orders of magnitude than the ones used in this study that would most likely result in lower As concentration especially of the effluent. However, our results show that the altered rock could 
release As at concentrations higher than $10 \mu \mathrm{g} / \mathrm{L}$ for long periods of time independent of the rock bed thickness consistent with those observed under in situ conditions (Tabelin et al., 2010). Also, because of the relatively low concentration of As in the effluent, it is most efficiently removed by adsorption. Therefore, As can be immobilized from the rock by enhancing adsorption processes through the introduction of artificial or natural adsorbents stable at the $\mathrm{pH}$ range of 7 9. This can be achieved by either mixing it with the rock or placing it at the bottom as an adsorption layer. It is also important to control the water residence time and the $\mathrm{pH}$ of the rockwater system by increasing the thickness of the rock bed and/or through the addition of natural soil covers with low permeability. The soil cover could also provide additional protection against the wind and other agents of weathering and erosion.

\section{CONCLUSIONS}

Recent and ongoing tunnel projects in Japan are excavating hydrothermally altered rocks containing elevated concentrations of As. These altered rocks are therefore potential sources of soil and groundwater pollution and must be disposed of properly. In order to design an effective countermeasure for these altered rocks, we conducted column experiments to understand the factors affecting the mobilization and speciation of As at conditions similar to those encountered during the actual disposal of the altered rocks. Variations in the infiltration rate, bulk density and rock bed thickness showed similar effects on the mobility of As because of their identical effect on the water residence time. Higher infiltration rate, thinner rock bed and higher bulk density all resulted in shorter water residence time. A shortened water residence time reduced the dissolution of $\mathrm{O}_{2}$ and $\mathrm{CO}_{2}$ into the pore water, increased the $\mathrm{pH}$ especially during the first 20 weeks, and limited the extent of Fe-oxyhydroxide/oxide precipitation. All of these resulted in 
higher As concentration in the effluent. The importance of $\mathrm{pH}$ in As mobilization was also more pronounced in the columns, with small variations in the $\mathrm{pH}$ of the rock-water system translating to several folds of As concentration increase in the effluent.

The inorganic As species present in the leachates and effluents were predominantly As[V] under conditions close to steady state. However, instances where As[III] predominated in the effluent were also observed, which could be attributed to the $\mathrm{pH}$-dependent adsorption of As species. After reaching apparent steady-state conditions, the altered rock was still capable of attenuating additional As loadings, even if it was the more mobile As[III] species, probably due to the presence of precipitated $\mathrm{Fe}-\mathrm{Al}$ oxyhydroxides/oxides, clay minerals and organic matter that could act as strong adsorbents of As as well as through the possible oxidation of As[III] to As[V]. This phenomenon might occur around the bottom half of the column that was more saturated with water. The primary mechanisms controlling the mobilization of As from altered rock are dissolution of soluble As-bearing phases, pyrite oxidation and adsorption onto Fe and Al-oxyhydroxide/oxide precipitates. The pH-dependent adsorption of As[III $]$ and As[V] is an important mechanism of As release especially in the earlier stages but in the long run pyrite oxidation and adsorption are expected to control the mobilization of As from the rock.

\section{ACKNOWLEDGMENT}

The authors wish to thank Dr. Kaye S. Savage and the other anonymous reviewers for their valuable inputs in this paper.

\section{References}

Acharyya, S.K., Lahiri, S., Raymahashay, B.C., Bhowmik, A., 2000. Arsenic toxicity of groundwater in parts of the Bengal basin in India and Bangladesh: the role of Quarternary stratigraphy and Holecene sea level-fluctuation. Environmental Geology 39(10), 1127-1137.

Aiuppa, A., Avino, R., Brusca, L., Caliro, S., Chiodini, G., D’Alessadro, W., Favara, R., Federico, C., Ginevra, W., Inguaggiato, S., Longo, M., Pecoraino, G., Valenza, M., 2006. 
Mineral control of arsenic content in thermal waters from volcano-hosted hydrothermal systems: Insights from the island of Ischia and Phlegrean Fields. Chemical Geology 229, 313 - 330.

Akai, J., Izumi, K., Fukuhara, H., Masuda, H., Nakano, S., Yoshimura, T., Ohfuji, H., Anwar, H.M., Akai, K., 2004. Mineralogical and geomicrobial investigations on groundwater arsenic enrichment in Bangladesh. Applied Geochemistry 19, 215-230.

Al-Abed, S.R., Hageman, P.L., Jegadeesan, G., Madhavan, N., Allen, D., 2006. Comparative evaluation of short-term leach tests for heavy metal release from mineral processing waste. Sci. Total Envi. 364, 14-23.

Allen, K.D., Hahn, G.A., 1994. Geology of Sunbeam and Grouse Creek gold-silver deposits, Yankee Fork mining district, Eocene Challis volcanic field, Idaho: a volcanic dome and volcaniclastic-hosted epithermal system. Econ. Geol. 89, 1964-1982.

Appelo, C.A.J, Postma, D., 2005. Geochemistry, groundwater and pollution, $2^{\text {nd }}$ ed. A.A. Balkema Publishers, London.

American Society for Testing and Materials, 1989. Standard test method for leaching solid waste in column apparatus (Method D 4874-89). American Society of Testing and Materials, Philadelphia, PA.

Bethke, C.M., 1992. The Geochemist's Workbench - A User's guide to Rxn, Act2, Tact, React and Gtplot. University of Illinois, Urbana, Illinois.

Bostick, B. C., Fendorf, S., 2003. Arsenite sorption on troilite $(\mathrm{FeS})$ and pyrite $\left(\mathrm{FeS}_{2}\right)$. Geochim. Cosmochim. Acta 67, 909-921.

Bothe Jr., J.V., Brown, P.W., 1999. The stabilities of calcium arsenates at $23 \pm 1{ }^{0} \mathrm{C}$. Journal of Hazardous Materials 69, 197-207.

Chandra, A.P., Gerson, A.R., 2010. The mechanisms of pyrite oxidation and leaching: A fundamental perspective. Surface Science Reports 65, 293-315.

Chiu, V.Q., Hering, J.G., 2000. Arsenic adsorption and oxidation at manganite surfaces. 1. Method for simultaneous determination of adsorbed and dissolved arsenic species. Environ. Sci. Technol. 34, 2029-2034.

Clevenger, T.E., 1990. Use of sequential extraction to evaluate the heavy metals in mining wastes. Water, Air and Soil Pollution 50, 241-253.

Cornelis, G., Anette-Johnson, C., Van Gerven, T., Vandecasteele, C., 2008. Leaching mechanisms of oxyanionic metalloid and metal species in alkaline solid wastes: a review. Applied Geochemistry 23, 955-976. 
Davis, A., Ashenberg, D., 1989. The aqueous geochemistry of the Berkeley pit, Butte, Montana, U.S.A. Applied Geochemistry 4, 23-36.

Davis, A., Bellehumeur, T., Hunter, P., Hanna, B., Fennemore, G.G., Moomaw, C., Schoen, S., 2006. The nexus between groundwater modeling, pit lake chemogenesis and ecological risk from arsenic in the Getchell main pit, Nevada, USA. Chemical Geology 228, 175-196.

Das, D., Samanta, S., Mandal, B.K., Chowdhury, T.R., Chanda, C.R., Chowdry, P.P., Basu, G.K., Chakraborti, D., 1996. Arsenic in groundwater in six districts of West Bengal, India. Environmental Geochemistry and Health 18, 5-15.

De Donato, P., Mustin, C., Benoit, R., Erre, R., 1993. Spatial distribution of iron and sulphur species on the surface of pyrite. Applied Surface Science 68, 81-93.

Dousova, B., Machovic, V., Kolousek, D., Kovanda, F., Dornicak, V., 2003. Sorption of As (V) species from aqueous solution. Water Air and Soil Pollution 149, 251-267.

Dowling, C.B., Poreda, R.J., Basu, A.R., Peters, S.L., Aggarwal, P.K., 2002. Geochemical study of arsenic release mechanisms in the Bengal Basin groundwater. Water Resources Research 38(9), 1173.

Dzombak, D.A., Morel, F.M.M., 1990. Surface Complexation Modeling: Hydrous Ferric Oxide, John Wiley and Sons, New York.

Eary, L.E., 1999. Geochemical and equilibrium trends in mine pit lakes. Applied Geochemistry 14, 963-987.

Evangelou, V.P., 1995. Pyrite oxidation and its control. CRC Press, New York.

Ghosh, M.M., Teoh, R.S., 1985. Adsorption of arsenic on hydrous aluminum oxide. In:

Proceedings of the Seventh Mid-Atlantic Industrial Waste Conference, Lancaster, PA, 139-155.

Halbach, P., Pracejus, B., Marten, A., 1993. Geology and mineralogy of massive sulfide ores from Okinawa trough, Japan. Econ. Geol. 88, 2210-2225.

Horton, T.W., Becker, J.A., Craw, D., Koons, P.O., Page Chamberlain, C., 2001. Hydrothermal arsenic enrichment in an active mountain belt: Southern Alps, New Zealand. Chemical Geology $177,323-339$.

Huston, D.L., Sie, S.H., Sauter, G.F., Cook, D.R., Both, R.A., 1995. Trace elements in sulfide minerals from eastern Australian volcanic-hosted massive sulfide deposits: Part 1. Proton microprobe analyses of pyrite, chalcopyrite and sphalerite, and Part 2. Selenium levels in pyrite: comparison with $\delta^{34} \mathrm{~S}$ values and implications for the source of sulfur in volcanogenic hydrothermal systems. Econ. Geol. 90, 1167-1196.

Igarashi, T., Imagawa, H., Uchiyama, H., Asakura, K., 2008. Leaching behavior of arsenic from various rocks by controlling geochemical conditions. Miner. Eng. 21, 191-199. 
Impellitteri, C.A., 2004. Effects of $\mathrm{pH}$ and competing anions on the speciation of arsenic in fixed ionic strength solutions by solid phase extraction cartridges. Water Res. 38, 1207-1214.

Jang, J.H., Dempsey, B.A., 2008. Coadsorption of arsenic(III) and arsenic(V) onto hydrous ferric oxide: effects of abiotic oxidation of arsenic(III), extraction efficiency, and model accuracy. Environ. Sci. Technol. 42, 2893-2898.

Jeong, Y., Maohong, F., Van Leeuwen, J., Belczyk, J.F., 2007. Effect of competing solutes on arsenic (V) adsorption using iron and aluminium oxides. Journal of Environment Sciences 19, 910-919.

Jerz, J.K., Rimstidt, J.D., 2004. Pyrite oxidation in moist air. Geochim. Cosmochim. Acta 68, 701-714.

Koshimizu, S., Kim, C.W., 1986. Fission-track dating of the Cenozoic formations in CentralEastern Hokkaido, Japan (part 1): Kamishiyubetsu and Kitamifuji district. Jour. Geological Society of Japan, 92, 477-487. (Paper in Japanese with English abstract)

Levy, D.B., Custis, K.H., Casey, W.H., Rock, P.A., 1997. The aqueous geochemistry of the abandoned Spenceville copper pit, Nevada County, California. Journal of Environmental Quality 26, 233-243.

Lin, Z., Puls, R.W., 2000. Adsorption, desorption and oxidation of arsenic affected by clay minerals and aging process. Environmental Geology 39(7), 753-759.

Liu, Z., Dreybrodt, W., 1997. Dissolution kinetics of calcium carbonate minerals in $\mathrm{H}_{2} \mathrm{O}-\mathrm{CO}_{2}$ solutions in turbulent flow: the role of the diffusion boundary layer and the slow reaction $\mathrm{H}_{2} \mathrm{O}+$ $\mathrm{CO}_{2} \leftrightarrow \mathrm{H}^{+}+\mathrm{HCO}_{3}{ }^{-}$. Geochim. Cosmochim. Acta 61(14), 2879-2889.

Marumo, K., Ebashi, T., Ujiie, T., 2003. Heavy metal concentrations, leachabilities and lead isotope ratios of Japanese soils. Shigen - Chisitsu 53(2), 125-146. (Paper in Japanese with English abstract)

Meng, X., Bang, S., Korfiatis, G.P., 2000. Effects of silicate, sulfate, and carbonate on arsenic removal by ferric chloride. Water Res. 34, 1255-1261.

Nickson, R.T., McArthur, K.M., Ravenscroft, J.M., Burgess, W.G., Ahmed, K.M., 2000. Mechanism of arsenic release to groundwater, Bangladesh and West Bengal. Applied Geochemistry 15, 403-413.

O’Day, P.A., Vlassopoulos, D., Root, R., Rivera, N., 2004. The influence of sulfur and iron on dissolved arsenic concentrations in the shallow subsurface under changing redox conditions. Proceedings of the National Academy of Sciences 101 (38), 13703-13708.

Ostwald, J., England, B.M., 1977. Notes on framboidal pyrite from Allandale, New South Wales, Australia. Mineral. Deposita 12, 111-116. 
Parkhurst, D.L., Appelo, C.A.J., 1999. User's guide to PHREEQC (Version 2) - A computer program for speciation, batch-reactions, one-dimensional transport, and inverse geochemical calculations. U.S. Geological Survey, Denver, CO.

Plummer, L.N., Wigley, T.M.L., Parkhurst, D.L., 1978. The kinetics of calcite dissolution in $\mathrm{CO}_{2}$-water at $5{ }^{0} \mathrm{C}$ to $60{ }^{0} \mathrm{C}$ and 0.0 to 1.0 atm $\mathrm{CO}_{2}$. Am. J. Sci. 278, 179-216.

Raven, K.P., Jain, A., Loeppert, R.H., 1998. Arsenite and arsenate adsorption on ferrihydrite: kinetics, equilibrium and adsorption envelopes. Environ. Sci. Technol. 32, 344-349.

Redman, A.D., Macalady, D.L., Ahmann, D., 2002. Natural organic matter affects arsenic speciation and sorption onto hematite. Environ. Sci. Technol. 36, 2889-2896.

Rimstidt, J.D., Vaughan, D.J., 2003. Pyrite oxidation: A state-of-the-art assessment of the reaction mechanism. Geochim. Cosmochim. Acta 67(5), 873-880.

Savage, K.S., Ashley, R.P., Bird, D.K., 2009. Geochemical evolution of a high arsenic, alkaline pit-lake in the Mother Lode Gold District, California. Economic Geology 104, 1171-1211.

Schaufuss, A.G., Nesbitt, H.W., Kartio, I., Laajalehto, K., Bancroft, G.M., Szargan, R., 1998. Reactivity of surface chemical states on fractured pyrite. Surface Science 411 (3), 321-328.

Sengupta, A.K., 2002. Environmental Separation of Heavy Metals - Engineering Processes. Lewis Publishers, London.

Smedley, P.L., Kinniburgh D.G., 2002. A review of the source, behavior and distribution of arsenic in natural waters. Applied Geochemistry 17, 517-568.

Stollenwerk, K.G., 2003. Geochemical processes controlling transport of arsenic in groundwater: a review. In: Welch, A.H., Stollenwerk, K.G., editors. Arsenic in ground water. Boston: Kluwer Academic Publishers, pp. 67-100.

Tabelin, C.B., Igarashi, T., 2009. Mechanisms of arsenic and lead release from hydrothermally altered rock. Journal of Hazardous Materials 169, 980-990.

Tabelin, C.B., Igarashi, T., Tamoto, S., 2010. Factors affecting arsenic mobility from hydrothermally altered rock in impoundment-type in situ experiments. Minerals Engineering 23, 238-248.

Takahashi, T., Fujii, K., Igarashi, T., Kaketa, K., Yamada, N., 2011. Distribution properties and leaching of arsenic by the hydrothermally-altered rocks of Nakakoshi Area, central Hokkaido, Japan. Journal of the Japan Society of Engineering Geology 52(2), 46-54. (paper in Japanese with English abstract)

Tanaka, T., 1988. Distribution of arsenic in the natural environment with emphasis on rocks and soils. Applied Organometallic Chemistry 2 (4), 283-295. 
Tempel, R.N., Shevenell, L.A., Lechler, P., Price, J., 2000. Geochemical modeling approach to predicting arsenic concentrations in a mine pit lake. Applied Geochemistry 15, 475-492.

Tessier, A., Campbell, G.C., Bisson, M., 1979. Sequential extraction procedure for the speciation of particulate trace metals. Analytical Chemistry 51, $844-850$.

Todd, E.C., Sherman, D.M., Purton, J.A., 2003. Surface oxidation of pyrite under ambient atmospheric and aqueous ( $\mathrm{pH}=2$ to 10 ) conditions: electronic structure and mineralogy from $\mathrm{X}$ ray absorption spectroscopy. Geochim. Cosmochim. Acta 67(5), 881-893.

Tsushima, N., Matsueda, H., Ishihara, S., 1999. Polymetallic mineralization at the Nakakoshi copper deposits, central Hokkaido, Japan. Resource Geology 49, 89-97.

Wang, S., Mulligan, C., 2006. Natural attenuation processes for remediation of arsenic contaminated soils and groundwater. Journal of Hazardous Materials 138(3), 459-470.

Webster, J.G., 1999. Arsenic, in: Marshall, C.P., Fairbridge, R.W. (Eds), Encyclopaedia of Geochemistry. Chapman Hall, London, pp. 21-22.

Wilkie, J.A., Hering, J.G., 1996. Adsorption of arsenic onto hydrous ferric oxide: effects of adsorbate/adsorbent ratios and co-occurring solutes. Colloid Surf. A 107, 97-110.

Zhu, Y.N., Zhang, X.H., Xie, Q.L., Wang, D.Q., Cheng, G.W., 2006. Solubility and stability of calcium arsenates at $25{ }^{\circ} \mathrm{C}$. Water, Air and Soil Pollution 169, 221-238. 
Figure Captions

FIGURE 1 Schematic diagram of the columns used in the experiments.

FIGURE 2 Evolution of total As, arsenate (As[V]), arsenite (As[III]) and $\mathrm{pH}$ with time in the batch experiments: (a) solid-liquid ratio $=1: 5$, (b) solid-liquid ratio $=1: 10$, (c) $\mathrm{pH}$ change with time, and (d) Eh change with time.

FIGURE 3 Effects of infiltration rate on the $\mathrm{PV}, \mathrm{pH}, \mathrm{Eh}, \mathrm{As}, \mathrm{EC}, \mathrm{Ca}^{2+}, \mathrm{SO}_{4}{ }^{2-}$ and $\mathrm{Fe}$ concentration; (a) PV change with time, (b) $\mathrm{pH}$ change with PV, (c) Eh change with PV, (d) As concentration in the effluent with $\mathrm{PV}$, (e) EC change with PV, (f) $\mathrm{Ca}^{2+}$ concentration change with $\mathrm{PV},(\mathrm{g}) \mathrm{SO}_{4}{ }^{2-}$ concentration change with $\mathrm{PV}$, and (h) Fe concentration change with PV.

FIGURE 4 Effects of bulk density on the PV, pH, Eh, As, EC, $\mathrm{Ca}^{2+}, \mathrm{SO}_{4}{ }^{2-}$ and Fe concentration; (a) PV change with time, (b) $\mathrm{pH}$ change with PV, (c) Eh change with PV, (d) As concentration in the effluent with $\mathrm{PV}$, (e) EC change with $\mathrm{PV}$, (f) $\mathrm{Ca}^{2+}$ concentration change with $\mathrm{PV},(\mathrm{g}) \mathrm{SO}_{4}{ }^{2-}$ concentration change with $\mathrm{PV}$, and (h) Fe concentration change with PV.

FIGURE 5 Effects of rock bed thickness on the $\mathrm{PV}, \mathrm{pH}, \mathrm{Eh}, \mathrm{As}, \mathrm{EC}, \mathrm{Ca}^{2+}, \mathrm{SO}_{4}{ }^{2-}$ and $\mathrm{Fe}$ concentration; (a) PV change with time, (b) pH change with PV, (c) Eh change with PV, (d) As concentration in the effluent with PV, (e) EC change with PV, (f) $\mathrm{Ca}^{2+}$ concentration change with $\mathrm{PV},(\mathrm{g}) \mathrm{SO}_{4}{ }^{2-}$ concentration change with $\mathrm{PV}$, and (h) $\mathrm{Fe}$ concentration change with PV.

FIGURE 6 Correlation between As and $\mathrm{Ca}^{2+}$ concentrations in the effluents of all cases.

FIGURE 7 Results of the tracer and spike tests; (a) Br ${ }^{-}$concentration with time, and (b) As concentration before and after the spike test.

FIGURE 8 Evolution of total As, arsenate (As[V]) and arsenite (As[III]) concentrations with time in the effluent: (a)IR-case 2, (b) IR-case 3, (c) RT-case 1, and (d) RT-case 3.

FIGURE 9 Changes in the As contents of solid phases with depth in IR-case 3; (a) As content profiles of exchangeable and oxidizable fractions and (b) As content profiles of carbonates and reducible fractions with depth. Broken lines represent the initial As content of each phase.

FIGURE 10 Water and As distribution with depth; (a) Volumetric water content with depth, and (b) As concentration with depth.

FIGURE 11 Evolution of total As, arsenate (As[V]) and arsenite (As[III]) concentrations with depth in RT-case 1.

FIGURE 12 Saturation indices of Fe and Al oxides/oxyhydroxides, clay minerals and calcium arsenates with time: (a) IR-case 2, (b) IR-case 3, (c) RT-case 1 and (d) RT-case 3; Boehmite $[\mathrm{AlOOH}](\diamond)$, Gibbsite $\left[\mathrm{Al}(\mathrm{OH})_{3}\right](\square)$, Calcite $\left[\mathrm{CaCO}_{3}\right](\wedge)$, Gypsum $\left[\mathrm{CaSO}_{4} \cdot 2 \mathrm{H}_{2} \mathrm{O}\right](*), \mathrm{CaHAsO}_{4} \cdot \mathrm{H}_{2} \mathrm{O}(*), \mathrm{Ca}_{3}\left(\mathrm{AsO}_{4}\right)_{2} \cdot 3 \mathrm{H}_{2} \mathrm{O}(\mathrm{O})$, 
$\mathrm{Ca}_{4}(\mathrm{OH})_{2}\left(\mathrm{AsO}_{4}\right)_{2} \cdot 4 \mathrm{H}_{2} \mathrm{O}(+), \mathrm{Ca}_{5}\left(\mathrm{AsO}_{4}\right)_{3} \mathrm{OH}(-), \mathrm{Fe}(\mathrm{OH})_{3}(\square)$ and Lepidocrocite $[\mathrm{FeOOH}](\triangle)$.

FIGURE $13 \mathrm{Eh}-\mathrm{pH}$ predominance diagram of As at $25^{\circ} \mathrm{C}, 1.013$ bars, activity As $=10^{-6}$, activity $\mathrm{SO}_{4}{ }^{2-}=10^{-3}$. Each rectangular region represents the range of $\mathrm{Eh}$ and $\mathrm{pH}$ of the actual effluents collected. 


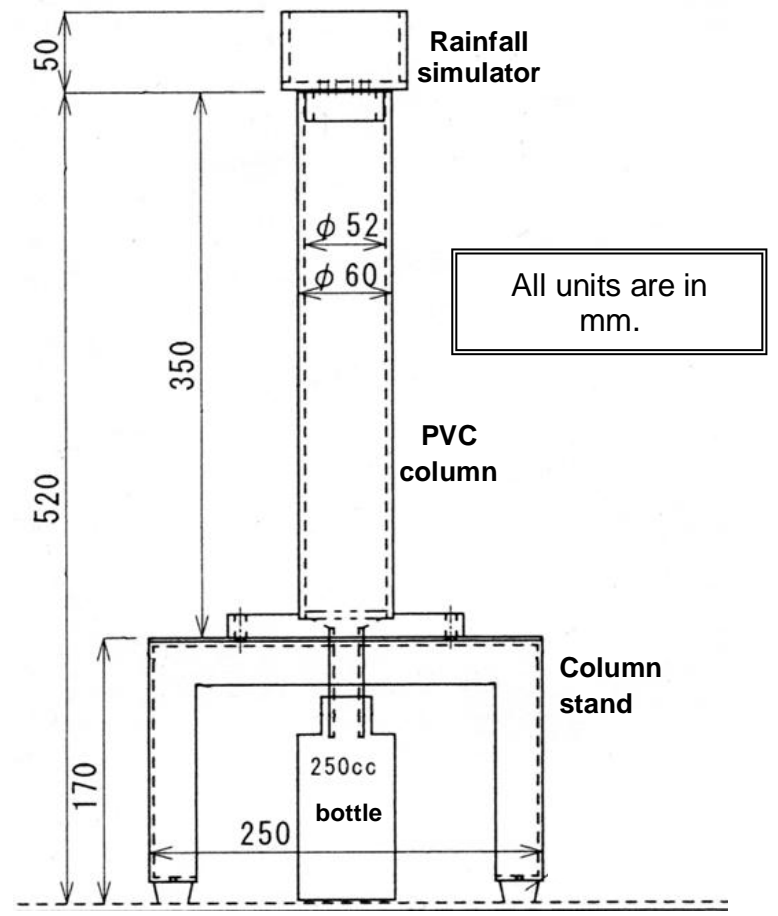

Figure 1
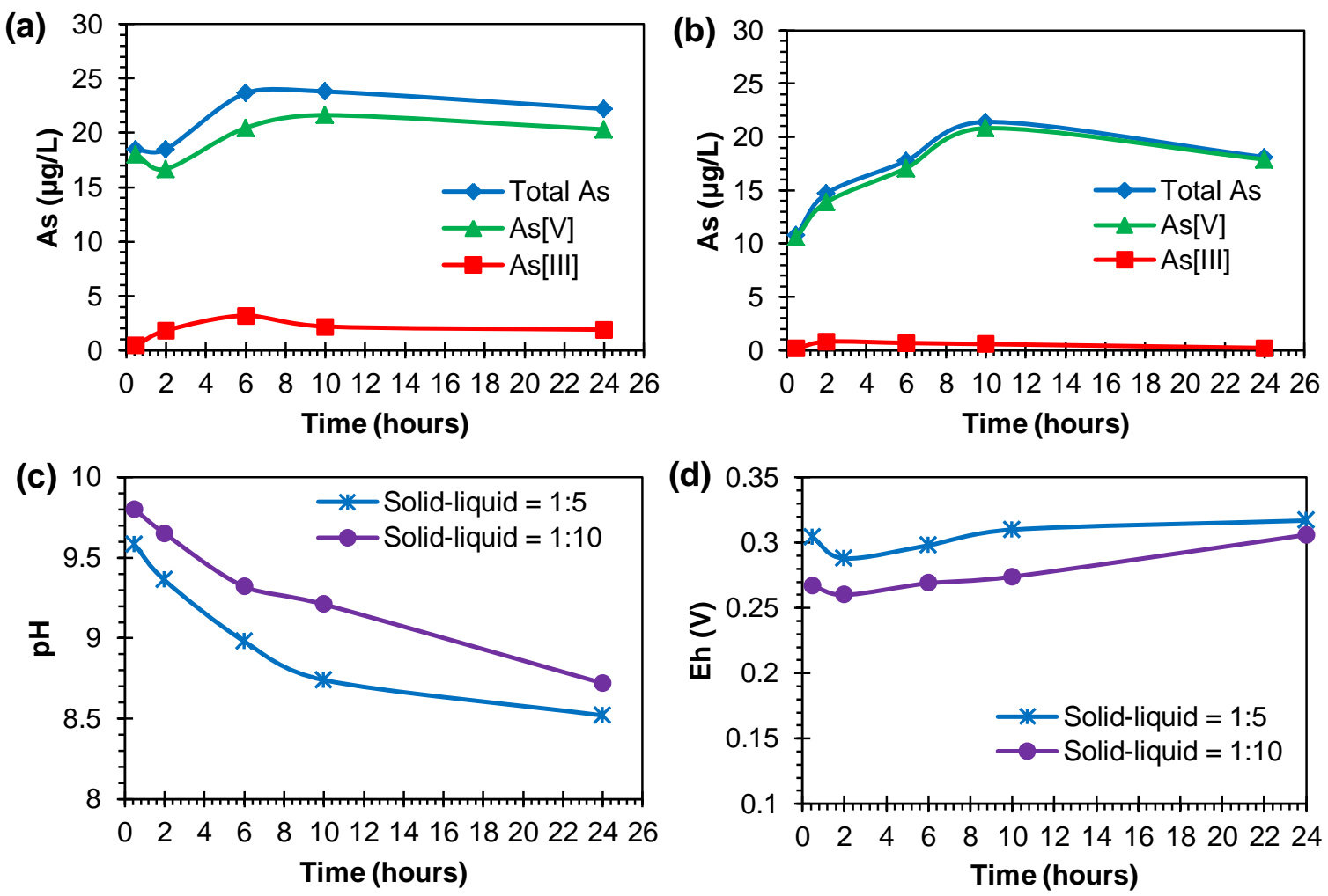

Figure 2 
(a)
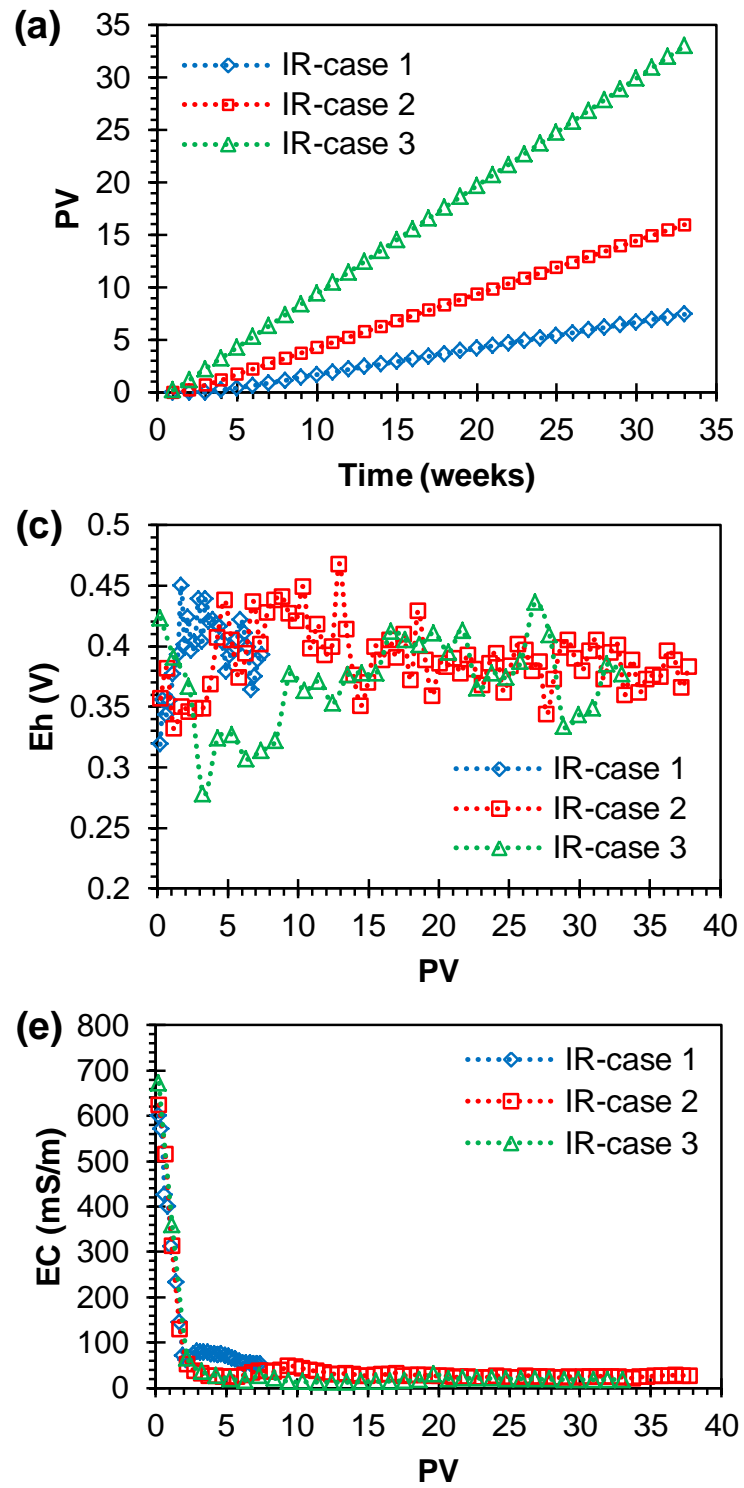
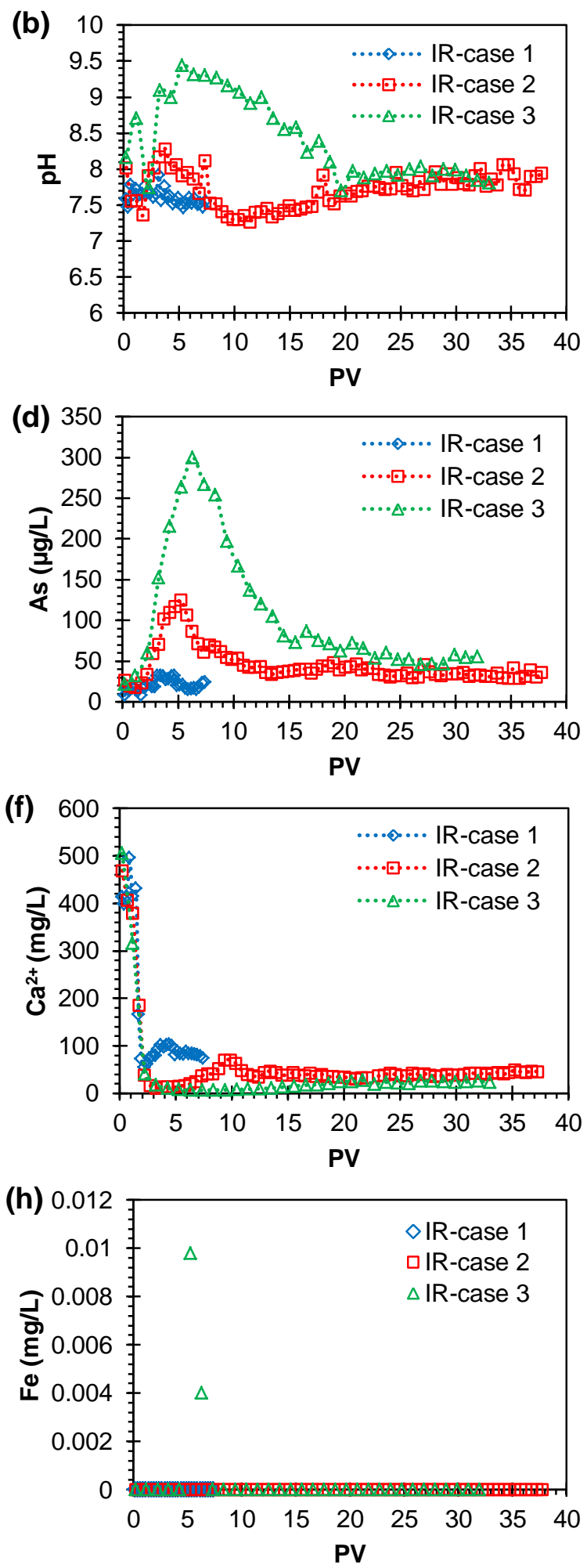

Figure 3 

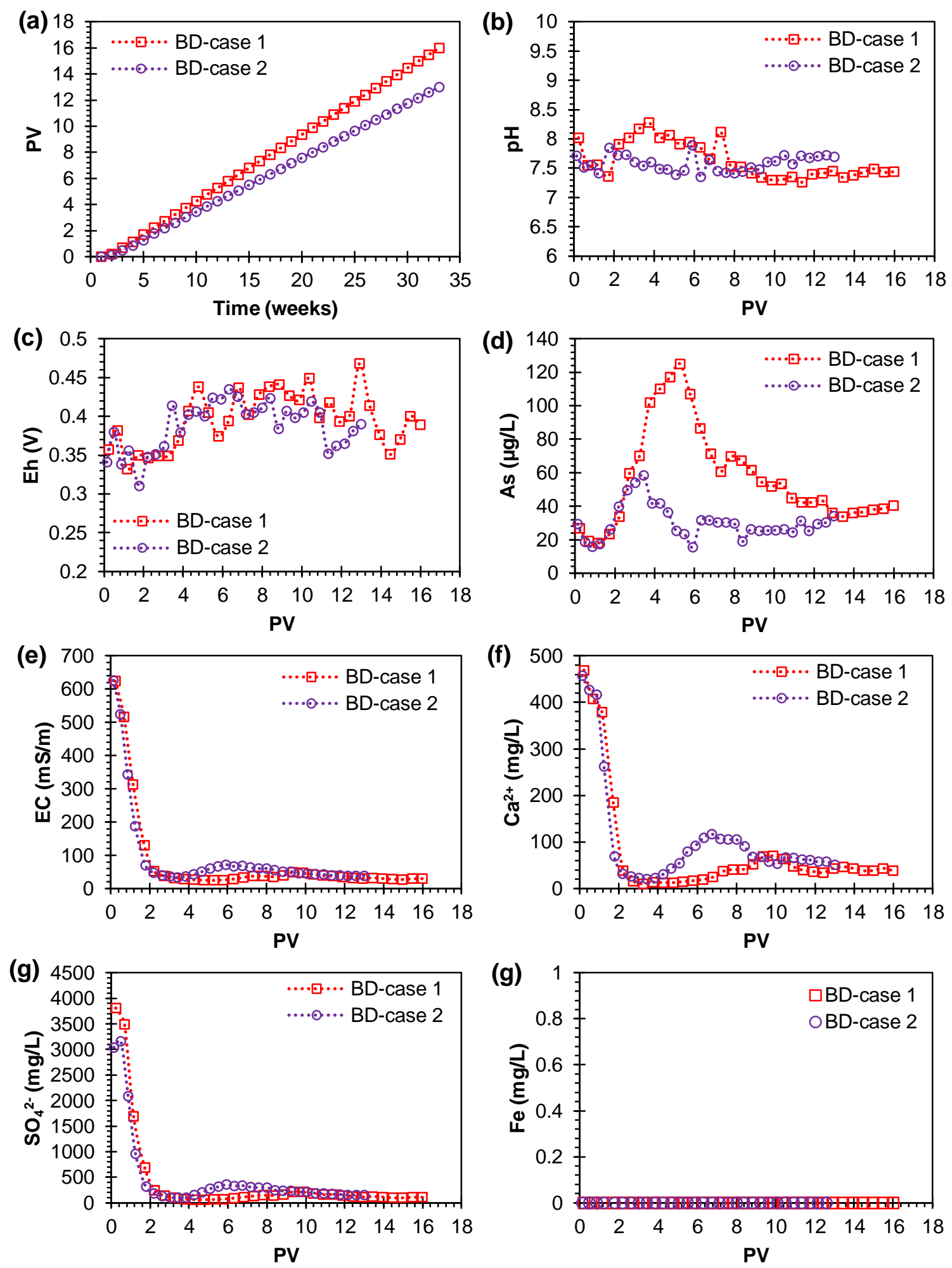

Figure 4 

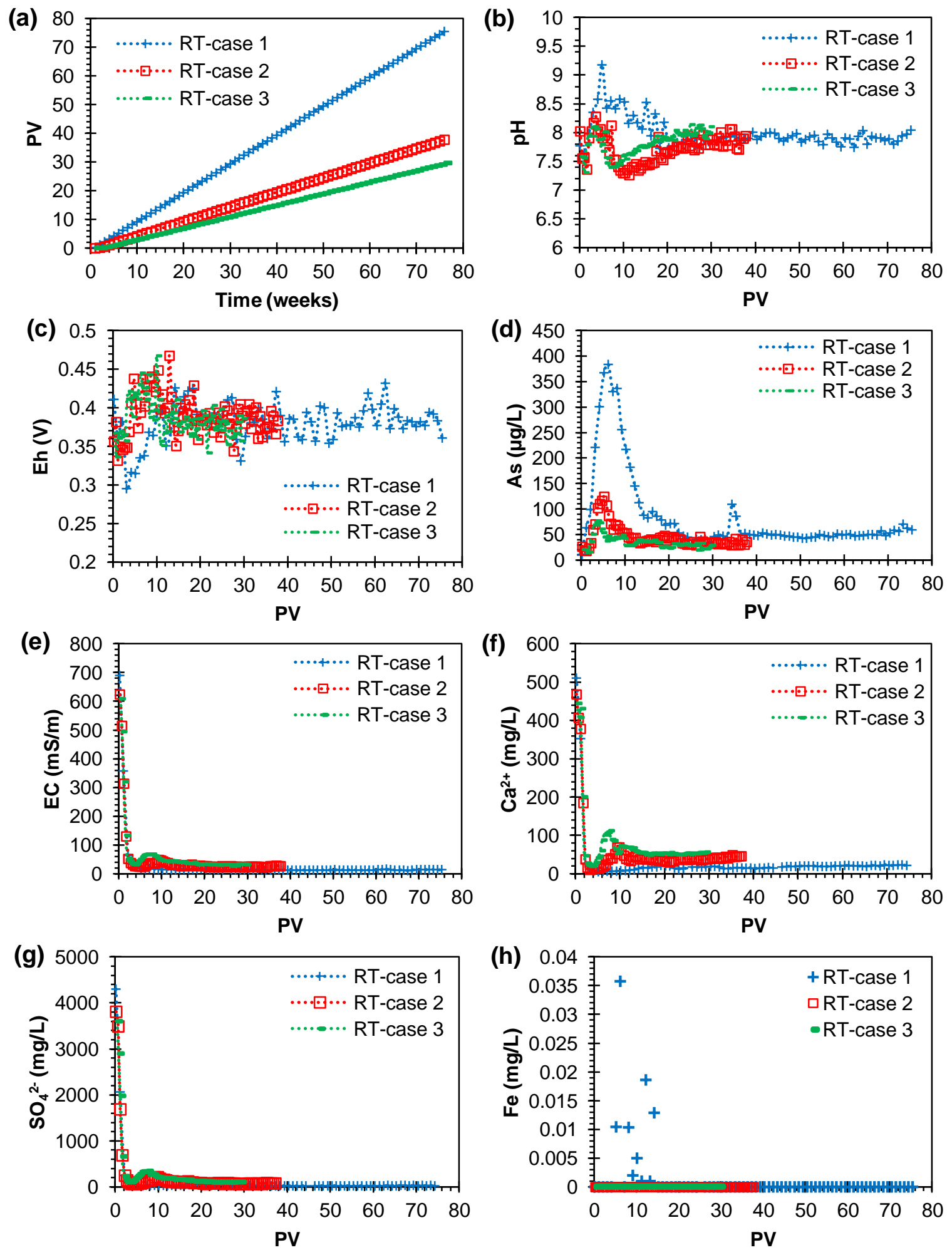

Figure 5 


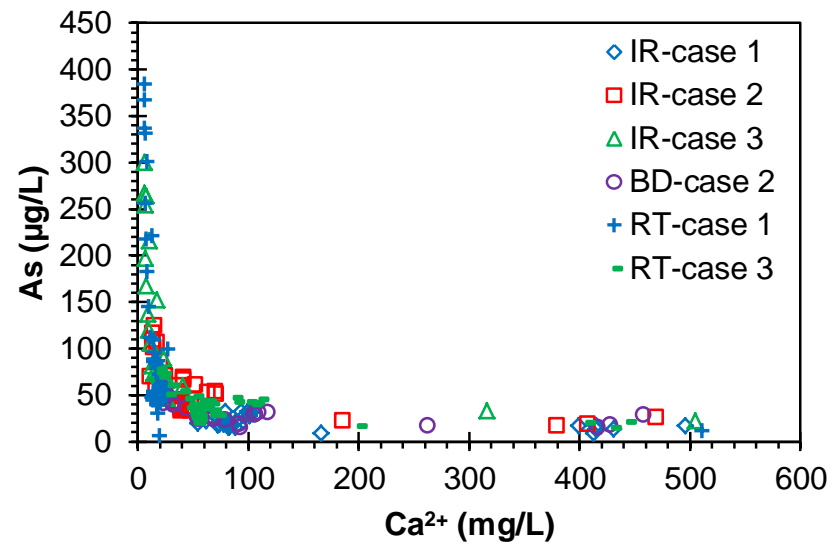

Figure 6
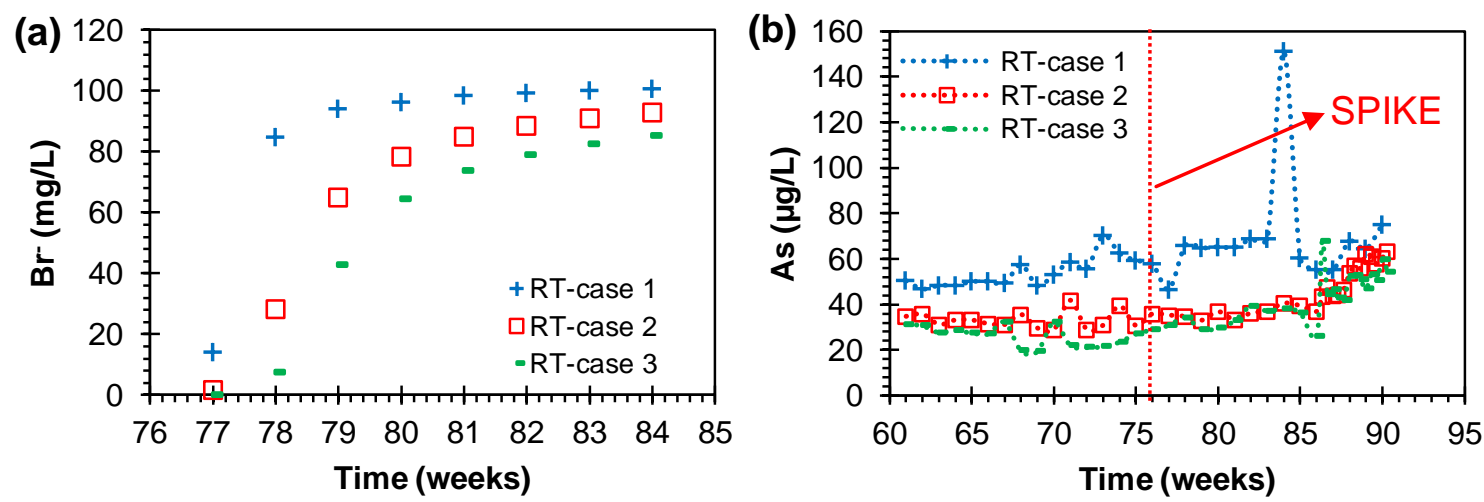

Figure 7 

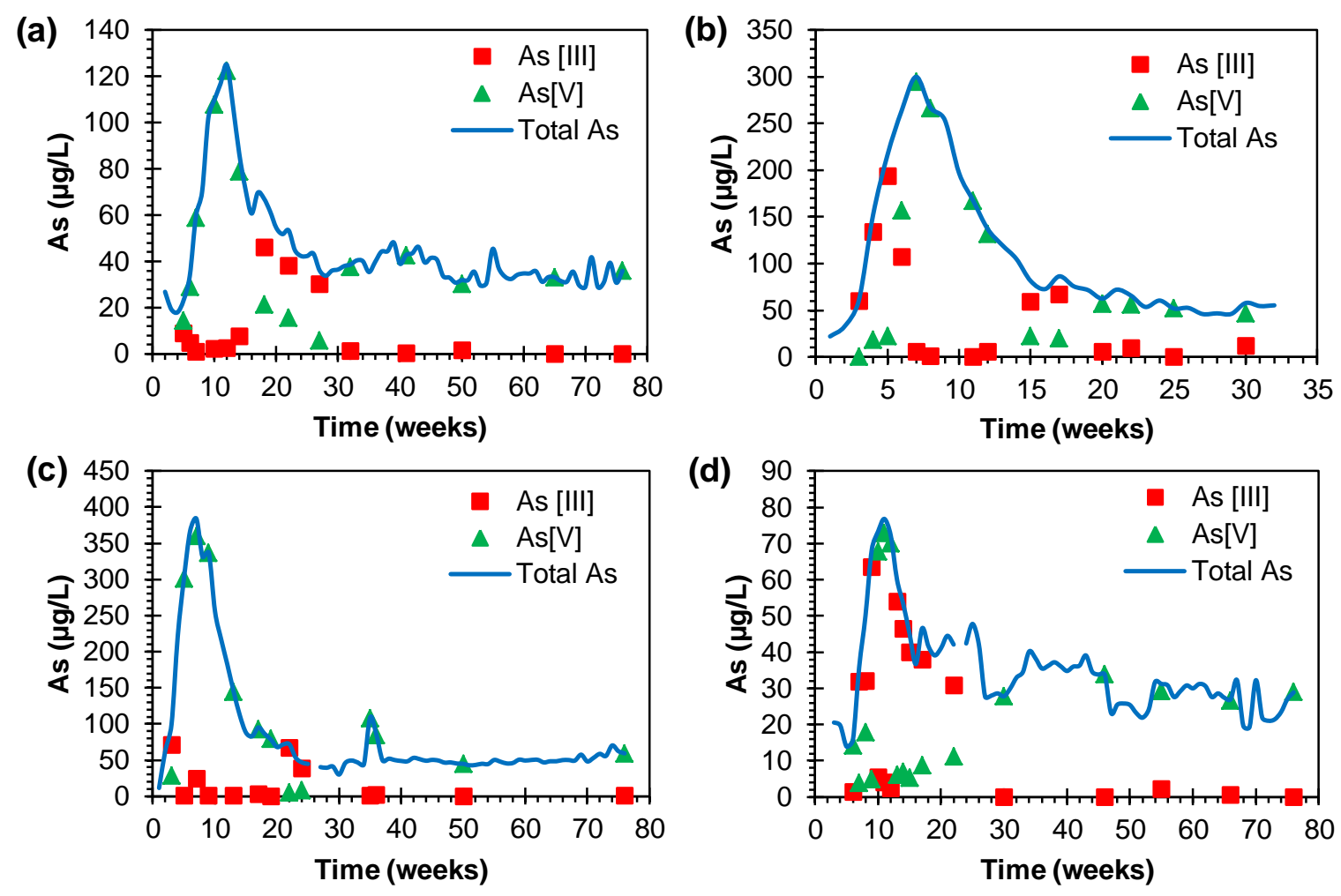

Figure 8
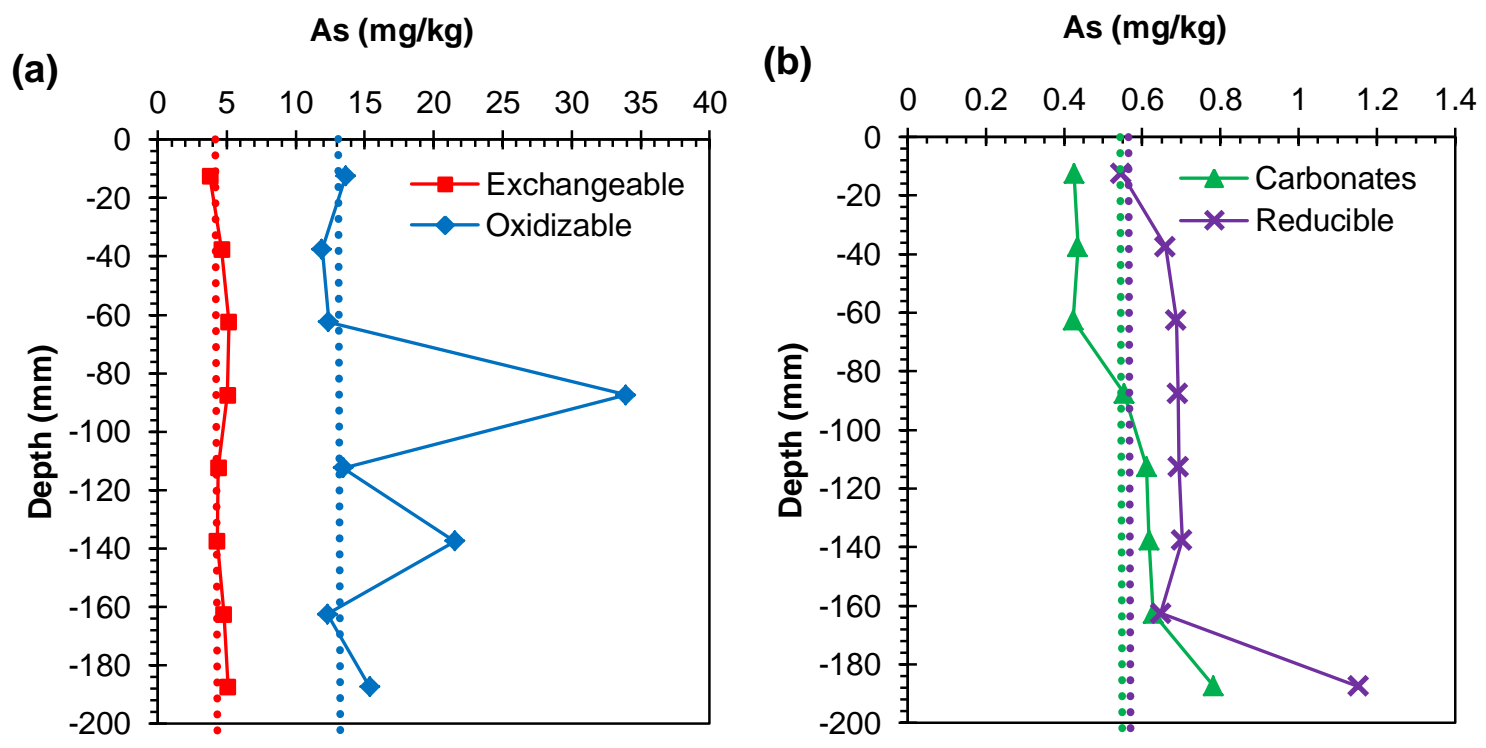

Figure 9 
(a) Volumetric water content $\left(\mathrm{cm}^{3} / \mathrm{cm}^{3}\right)$

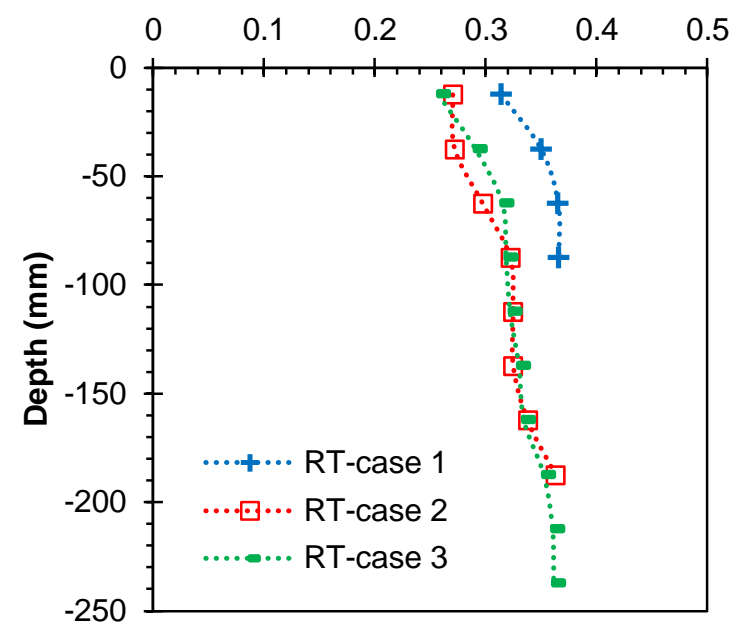

(b)

As ( $\mu \mathrm{g} / \mathrm{L})$

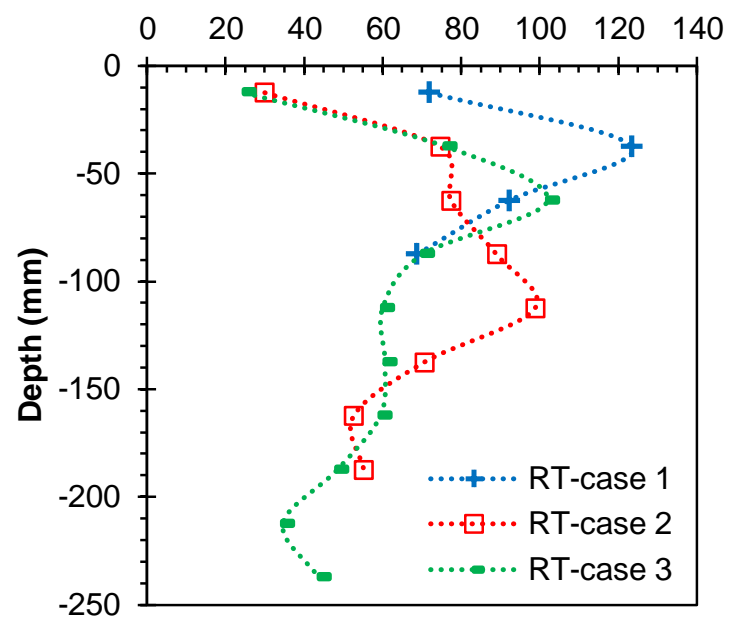

Figure 10

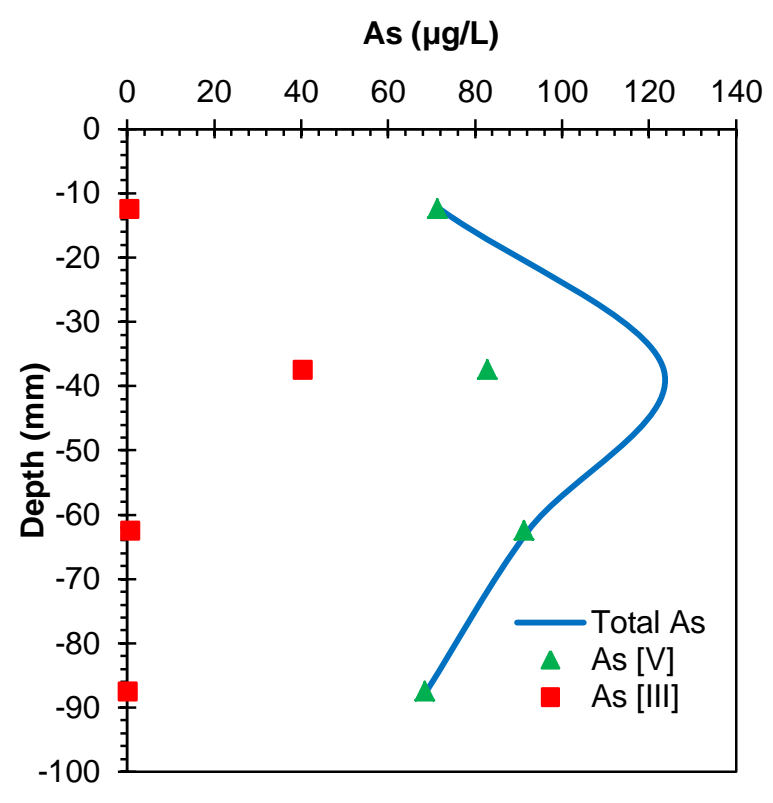

Figure 11 
(a)

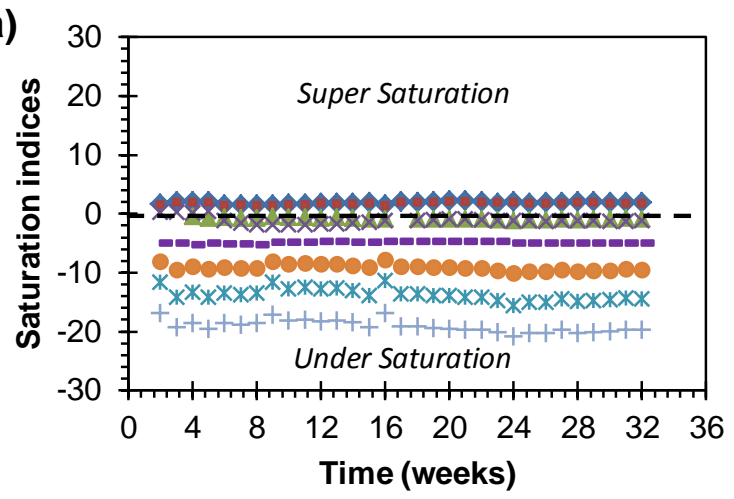

(c)

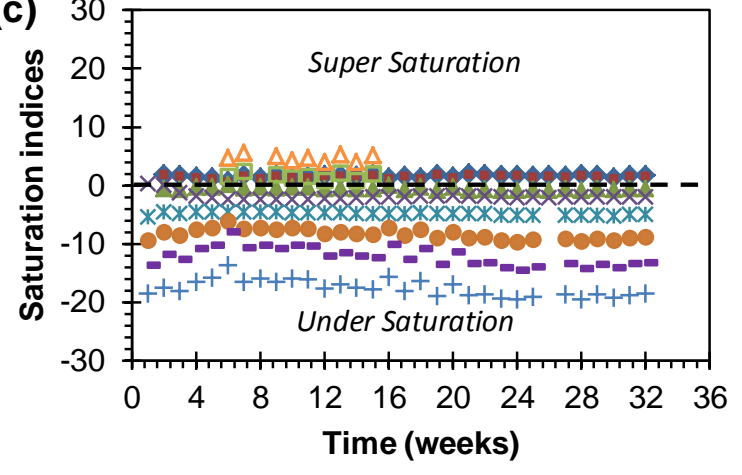

(b)
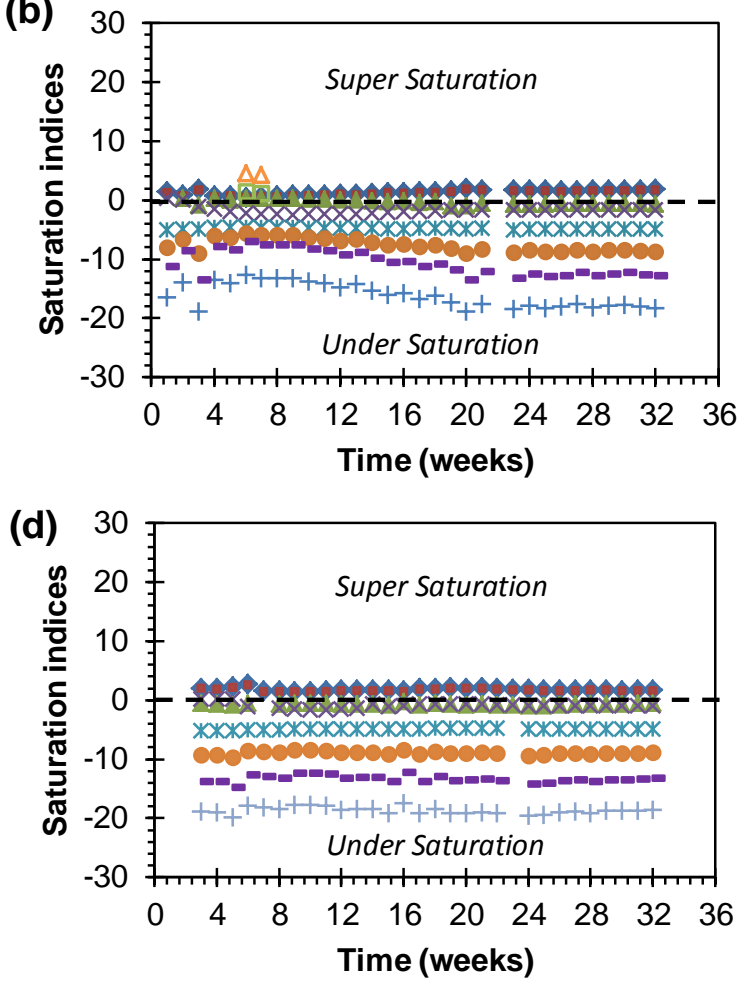

Figure 12

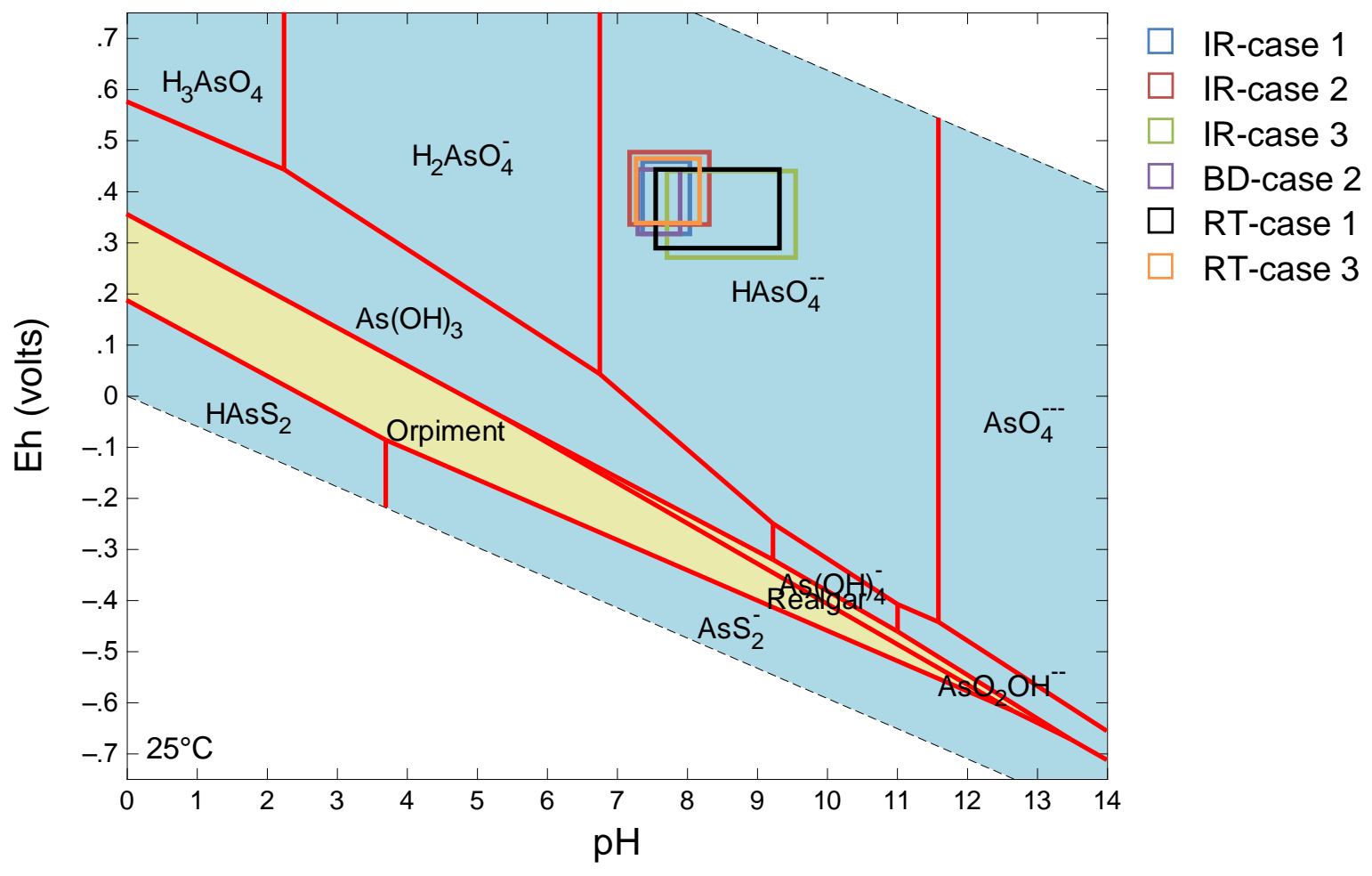

Figure 13 
Table 1. Sequential extraction for arsenic speciation

\begin{tabular}{|c|c|c|c|c|c|c|c|}
\hline Step & Extractant & $\mathrm{pH}$ & $\begin{array}{l}\text { Liquid } \\
\text { to solid } \\
\text { ratio } \\
(\mathrm{ml} / \mathrm{g}) \\
\end{array}$ & $\begin{array}{l}\text { Temperature } \\
\qquad\left({ }^{0} \mathrm{C}\right)\end{array}$ & $\begin{array}{l}\text { Duration } \\
\text { (h) }\end{array}$ & $\begin{array}{l}\text { Mixing } \\
\text { speed } \\
(\mathrm{rpm})\end{array}$ & Extracted phase \\
\hline 1 & $1 \mathrm{M} \mathrm{NaH}_{2} \mathrm{PO}_{4}$ & 5 & $20 / 1$ & 25 & 1 & 120 & Exchangeable \\
\hline 2 & $1 \mathrm{M} \mathrm{CH}_{3} \mathrm{COONa}$ & 5 & $20 / 1$ & 25 & 5 & 120 & Carbonates \\
\hline 3 & $\begin{array}{l}0.04 \mathrm{M} \mathrm{NH}_{2} \mathrm{OH} . \mathrm{HCl} \text { in } 25 \% \text { acetic } \\
\text { acid }\end{array}$ & - & $20 / 1$ & 50 & 5 & 120 & Fe-Mn oxides \\
\hline 4 & $\begin{array}{l}0.04 \mathrm{M} \mathrm{NH}_{2} \mathrm{OH} . \mathrm{HCl} \text { in } 25 \% \text { acetic } \\
\text { acid; } 30 \% \mathrm{H}_{2} \mathrm{O}_{2} ; 0.02 \mathrm{M} \mathrm{HNO}_{3}\end{array}$ & - & $36 / 1$ & 50 & 5 & 120 & $\begin{array}{l}\text { Sulfides and } \\
\text { organic matter }\end{array}$ \\
\hline 5 & \multicolumn{6}{|c|}{ Calculated } & Residual \\
\hline
\end{tabular}

Table 2. List of column experimental conditions

\begin{tabular}{|c|c|c|c|c|c|c|c|c|c|}
\hline $\begin{array}{l}\text { Column } \\
\text { name }\end{array}$ & $\begin{array}{c}\text { Infiltration } \\
\text { rate } \\
(\mathrm{mm} / \text { week })\end{array}$ & $\begin{array}{l}\text { Thickness of } \\
\text { rock bed } \\
(\mathrm{mm})\end{array}$ & $\begin{array}{c}\text { Bulk } \\
\text { density } \\
\left(\mathrm{g} / \mathrm{cm}^{3}\right)\end{array}$ & $\begin{array}{l}\text { Mass } \\
\text { rock } \\
(\mathrm{g})\end{array}$ & $\begin{array}{c}\text { Porosity } \\
(\%)\end{array}$ & $\begin{array}{c}\text { PV } \\
\text { Initial } \\
\left(\mathrm{cm}^{3}\right)\end{array}$ & $\begin{array}{c}\text { PV after } \\
\text { infiltration } \\
\left(\mathrm{cm}^{3}\right)\end{array}$ & $\begin{array}{l}\text { Tracer/ } \\
\text { Spike } \\
\text { test }\end{array}$ & $\begin{array}{c}\text { Increased } \\
\text { infiltration } \\
\text { rate }\end{array}$ \\
\hline IR-case 1 & 20 & 200 & 1.62 & 6888 & 40.7 & 173.9 & 163.4 & $\mathrm{No}$ & No \\
\hline IR-case 2 & 40 & 200 & 1.62 & 688 & 40.7 & 173.9 & 163.4 & Yes & Yes \\
\hline IR-case 3 & 80 & 200 & 1.62 & 688 & 40.7 & 173.9 & 163.4 & No & No \\
\hline BD-case 1 & 40 & 200 & 1.62 & 688 & 40.7 & 173.9 & 163.4 & Yes & Yes \\
\hline BD-case 2 & 40 & 220 & 1.47 & 688 & 46.2 & 216.5 & 199.5 & No & No \\
\hline RT-case 1 & 40 & 100 & 1.62 & 344 & 40.7 & 86.9 & 82.7 & Yes & No \\
\hline RT-case 2 & 40 & 200 & 1.62 & 688 & 40.7 & 173.9 & 163.4 & Yes & Yes \\
\hline RT-case 3 & 40 & 250 & 1.62 & 860 & 40.7 & 217.5 & 206.9 & Yes & Yes \\
\hline
\end{tabular}

**Note: IR-case 2, BD-case 1 and RT-case 2 are from the same column

Table 3. Chemical composition of the bulk rock sample

\begin{tabular}{lc}
\hline \hline Chemical name & Amount \\
\hline \hline $\mathrm{SiO}_{2}(\mathrm{wt} \%)$ & 58.7 \\
$\mathrm{TiO}_{2}(\mathrm{wt} \%)$ & 0.82 \\
$\mathrm{Al}_{2} \mathrm{O}_{3}(\mathrm{wt} \%)$ & 14.4 \\
$\mathrm{Fe}_{2} \mathrm{O}_{3}(\mathrm{wt} \%)$ & 6.22 \\
$\mathrm{MnO}(\mathrm{wt} \%)$ & 0.07 \\
$\mathrm{MgO}(\mathrm{wt} \%)$ & 3.49 \\
$\mathrm{CaO}(\mathrm{wt} \%)$ & 3.31 \\
$\mathrm{Na}_{2} \mathrm{O}(\mathrm{wt} \%)$ & 1.31 \\
$\mathrm{~K}_{2} \mathrm{O}(\mathrm{wt} \%)$ & 3.22 \\
$\mathrm{P}_{2} \mathrm{O}_{5}(\mathrm{wt} \%)$ & 0.13 \\
$\mathrm{~S}(\mathrm{wt} \%)$ & 0.2 \\
$\mathrm{As}(\mathrm{mg} / \mathrm{kg})$ & 23.6 \\
$\mathrm{LOI}(\mathrm{wt} \%)$ & 6.26 \\
$\mathrm{Total}$ & 98.1 \\
Organic C (wt $\%)$ & 0.23 \\
\hline \hline
\end{tabular}


Table 4. Mineralogical composition of the altered, unaltered and bulk excavated rock

\begin{tabular}{|c|c|c|c|c|c|c|c|c|c|c|c|c|c|c|}
\hline \multicolumn{2}{|c|}{ Sample description } & $\mathrm{Qz}$ & $\mathrm{Pl}$ & $\mathrm{Ab}$ & Ill & Chl & Kao & $\mathrm{Cal}$ & Sid & Ank & Py & Apy & Pyh & Mar \\
\hline \multirow{6}{*}{ 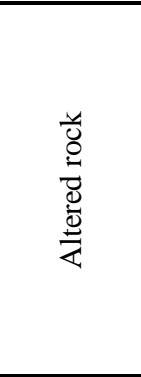 } & Altered slate & ++++ & +++ & & - & + & & ++ & & & - & & & \\
\hline & Strongly altered slate & ++++ & & + & - & + & + & +++ & - & & - & & & \\
\hline & $\begin{array}{l}\text { Strongly altered slate } \\
\text { near vein }\end{array}$ & ++++ & + & & + & + & ++ & & & & - & & & \\
\hline & White clay vein & + & & & & & ++++ & & + & + & & & & \\
\hline & Silicic rock & ++++ & & - & - & - & & & & & - & & & \\
\hline & Andesite & +++ & + & + & + & + & - & & & & & & & \\
\hline \multirow{4}{*}{ 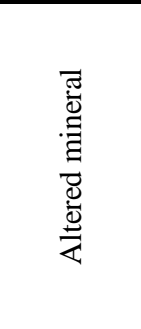 } & White vein & ++ & & & & & ++++ & & + & & & & & \\
\hline & White vein & & & & & & & ++++ & & & & & & \\
\hline & Vein & + & & & & & +++ & & +++ & & & & & \\
\hline & $\begin{array}{l}\text { Non magnetized bulk } \\
\text { pyrite }\end{array}$ & + & + & & & & & + & & & ++++ & & & \\
\hline $\begin{array}{l}\text { Unaltered } \\
\text { rock }\end{array}$ & Slate & ++++ & & & & - & & & & & & & & \\
\hline Bulk rock & $\begin{array}{l}\text { Mixed altered and } \\
\text { unaltered }\end{array}$ & ++++ & +++ & & & + & + & + & & & - & & & \\
\hline
\end{tabular}

++++: Very high; +++: high; ++: medium; +: minor; - : trace

Qz: Quartz; $\quad$ Pl: Plagioclase; Ab: Albite; Ill: Illite; $\quad$ Chl: Chlorite; Kao: Kaolinite; Cal: Calcite;

Sid: Siderite; $\quad$ Ank: Ankorite; Py: Pyrite; $\quad$ Apy: Arsenopyrite; $\quad$ Pyh: Pyrhotite; Mar: Marcasite

Table 5. Particle-size distribution of the sample used

\begin{tabular}{|c|c|c|c|c|}
\hline \multicolumn{3}{|l|}{$\%$ Sand } & $\%$ Silt & $\%$ Clay \\
\hline $0.85-2 \mathrm{~mm}$ & $0.025-0.85 \mathrm{~mm}$ & $0.075-0.250 \mathrm{~mm}$ & $0.005-0.075 \mathrm{~mm}$ & $<0.005 \mathrm{~mm}$ \\
\hline 28.1 & 25.7 & 16.6 & 22.3 & 7.3 \\
\hline
\end{tabular}

Table 6. Simulated $\mathrm{pH}, \mathrm{Ca}^{2+}$ and $\mathrm{SO}_{4}{ }^{2-}$ concentrations in a calcite-pyrite system under equilibrium conditions and measured values in RT-cases 1,2 and 3

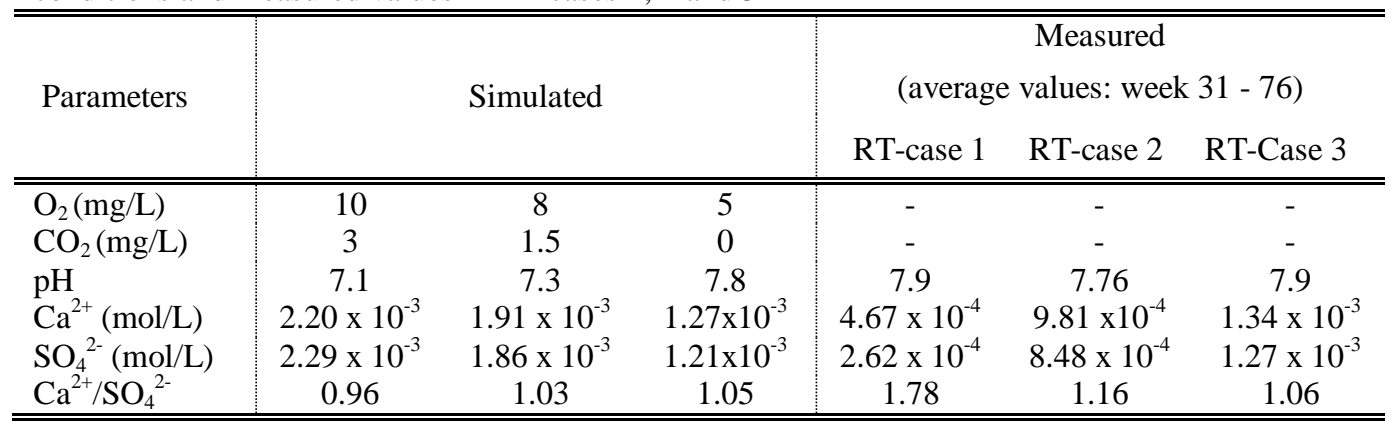

